\title{
REVIEW OF REACTOR SAFETY ANALYSES OF FAST AND LIQUID METAL. COOLED REACTORS
}

\author{
R. E. SHAVER
}

N. G. WITTENBROCK

NOVEMBER 1967

\section{AEC RESEARCH \& DEVELOPMENT REPORT}

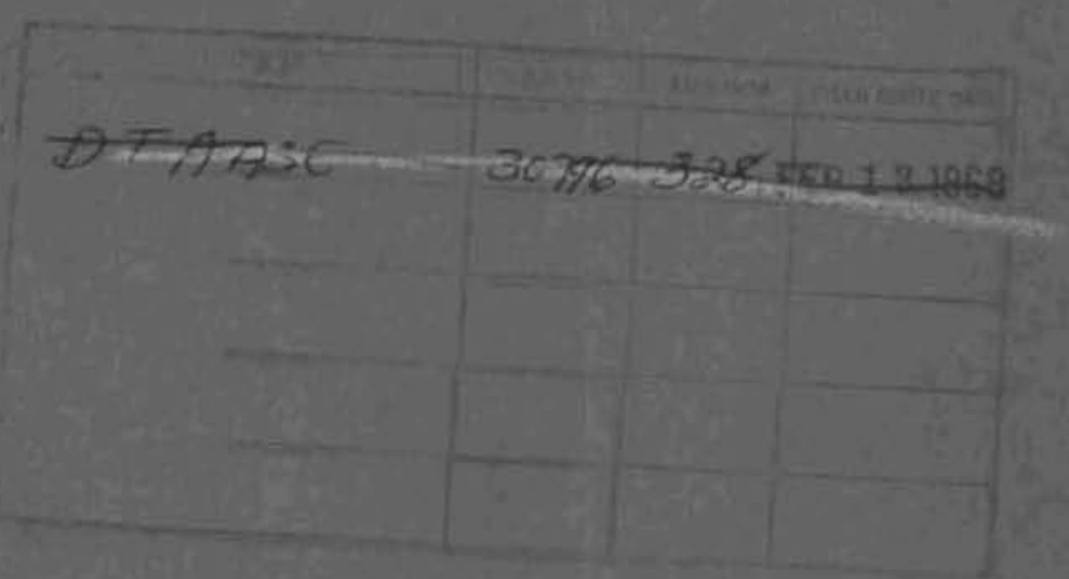

BATTELLE RORTHWEST

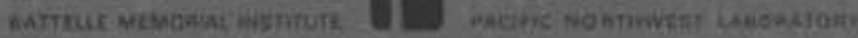

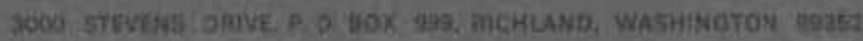




\title{
LEGAL NOTICE
}

This report was prepared as an octount of Government iponsored work. Neithar the United States, nar the Commission, not any portan acting on betiall of the Comminsioni

A. Makes any warranty or representation, expressed or implied, with respect to the occurccy, com. platenms, or usufulness of the infarmotion cantoined in this repoth or that the use of any informotion, apparatus, method, or process diasloued in this repon may not inftinge pelvatnly owned rights; of

B. Assumes any liabilities with respect to the use of, of for damogun retulting from the wee of any information, apparatus, melhod, or process disclosed in this report.

Ar used in the above, "petson octing on behalt of the Commistion" includen any emplayee or contractor of the commiasion, or emplayee of such cantrocter, 10 the extent that weth empleyet of sanIroctor of the Commission of employes of such controctor prepares, disseminutes, or provides occess to, any information purswant to his empleyment or contrad with the Camisinion, of his smployment with such contractor.

\author{
PACIFIC NORTHWEST LABORATORY \\ RICHLAND. WASRIRGTON \\ operated by \\ BATTELLE MEMORIAL INSTITUTE \\ for the \\ UNITED STATES ATOMIC ENERGY COMMISSION UNDER CONTRACT AT(45-1)-1830
}




\author{
BNWL- 477 \\ UC-80, Reactor Technology
}

\begin{abstract}
REVIEW OF REACTOR SAFETY ANALYSES
OF FAST AND LIQUID METAL COOLED REACTORS
\end{abstract}

By

R. E. Shaver

N. G. Wittenbrock

Nuclear Safety Section

Environmental Health Department

November 1967

FIRST UNRESTRICTED

DLTRIBLTION MABE

$n+13^{\prime} 67$

\author{
PACIFIC NORTHWEST LABORATORY \\ RICHLAND, WASHINGTON
}


Printed in the United States of America Available from

Clearinghouse for Federal Scientific and Technical Information National Bureau of Standards, U.S. Department of Commerce Springfield, Virginia 22151

Price: Printed Copy \$3.00; Microfiche $\$ 0.65$ 
TABLE OF CONTENTS

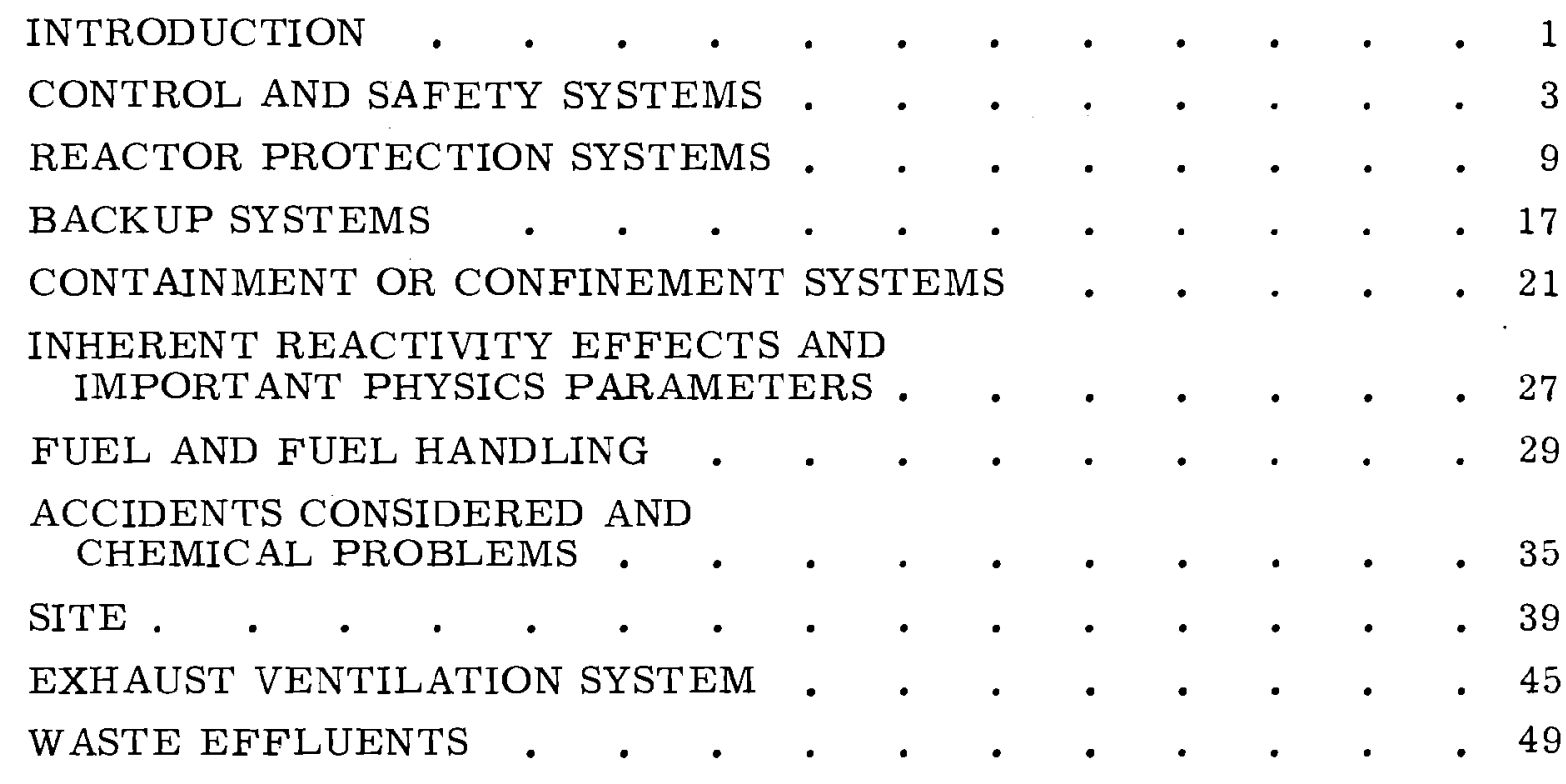




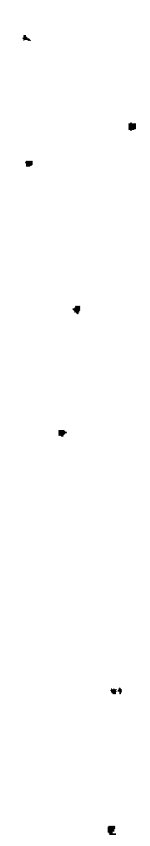




\author{
REVIEW OF REACTOR SAFETY ANALYSES \\ OF FAST AND LIQUID METAL COOLED REACTORS \\ R. E. Shaver and N. G. Wittenbrock
}

\title{
INTR ODUCTION
}

Safety analysis reports on United States fast and liquid metal cooled reactors were reviewed to gain a better understanding of the safety philosophy applied to the design of these facilities. This information was compiled to help guide the design and safety analysis of the Fast Flux Test Facility. No attempt was made to draw conclusions concerning the relative merit of different approaches and philosophies used by different reactor design teams.

The facilities reviewed were:

Enrico Fermi Atomic Power Plant (FERMI)

Hallam Nuclear Power Facility (HALLAM)

Southwest Experimental Fast Oxide Reactor (SEFOR)

Fast Reactor Test Facility (FARET)

Experimental Breeder Reactor No. 1 (EBR-I)

Experimental Breeder Reactor No. 2 (EBR-II)

Fast Reactor Zero Power Experiment (ZPR-III)

The information gathered from the safety analysis reports is presented in tabular form under the following subdivisions:

Table I. A Control and Safety Systems

Table I. B Reactor Protection Systems

Table II Backup Systems

Table III Containment or Confinement Systems

Table IV Inherent Reactivity Effects and Important

Physics Parameters

Table V Fuel and Fuel Handling

Table VI Accidents Considered and Chemical Problems

Table VII. A Site

Table VII。B Exhaust Ventilation System

Table VII, C Waste Effluents 


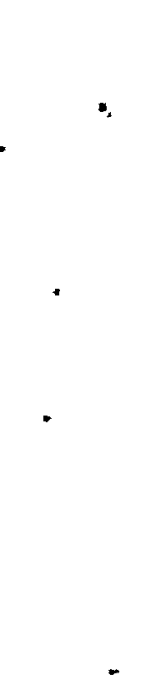


TABLE I. A. CONTROL AND SAFETY SYSTEMS

\begin{tabular}{|c|c|c|c|c|c|}
\hline Name & Reactor Type & Elements & Total Strength & $\begin{array}{l}\text { Individual } \\
\text { Strength }\end{array}$ & $\underline{\text { Speed Of Insertion }}$ \\
\hline FERMI $^{(1)}$ & $\begin{array}{l}\text { Fast breeder, } \\
\text { Na-cooled }\end{array}$ & $\begin{array}{l}\mathrm{B} 4 \mathrm{C} \text { (boron enriched } \\
\text { in } 10 \mathrm{~B} \text { ) safety }-8 \text { and } \\
\text { control }-2 \text { rods; motor } \\
\text { driven }(1 . a)\end{array}$ & $\$ 10.22^{(1 . a, g)}$ & $\begin{array}{l}\text { Safety }=\$ 1.00- \\
\$ 1.31(\max ) ; \\
\text { Control }=\$ 0.46(1 . \mathrm{a}, \mathrm{g})\end{array}$ & $\begin{array}{l}\text { Safety: (scram), } \$ 17 / \mathrm{sec} \text { or } \\
70 \mathrm{in} . / \mathrm{sec} ;(\text { fast rundown), } \\
10 \mathrm{ft} / \mathrm{min} \text { and } 1.6 \mathrm{in.} / \mathrm{min} \text { for } \\
\text { last } 6 \text { in. (1.a) }\end{array}$ \\
\hline Hallam $^{(2)}$ & $\begin{array}{l}\text { Thermal, } \\
\text { Na-graphite }\end{array}$ & $\begin{array}{l}\text { Vertical rods-19; } \\
\text { combination shim- } \\
\text { safety(2.a) }\end{array}$ & $14 \% \Delta \mathrm{k} / \mathrm{k}^{(2 . a)}$ & 1.5 to $2 \% \max (2 . a)$ & $0.9 \sec (2 . a)$ \\
\hline SEFOR ${ }^{(5)}$ & Fast, Na-cooled & $\begin{array}{l}10 \text { radial reflector } \\
\text { segments surrounding } \\
\text { core }\end{array}$ & $\$ 14$ & $\$ 1.40$ & $\begin{array}{l}\text { Speed of Drop--Scram: } \\
\$ 10 @ \$ 20 / \text { sec; automatic } \\
\text { rundown of "fine control" } \\
\text { segments provided--rate } \\
\text { not given. }\end{array}$ \\
\hline FARET $^{(6)}$ & Fast, Na-cooled & $\begin{array}{l}8 \text { subassemblies- } \\
\text { neutron-absorbing } \\
\text { rods (probably } \\
\left.\mathrm{B}_{4} \mathrm{C}\right) .\end{array}$ & $\begin{array}{l}\text { Reference Zoned } \\
\text { Core (R ZC): } 100 \% \\
\text { natural B }=0.04 \\
\triangle \mathrm{k} ; 75 \% \text { natural } \\
\mathrm{B}-25 \% 10 \mathrm{~B}=0.07 \\
\triangle \mathrm{k} ; 50 \% \text { natural } \\
\mathrm{B}-50 \% 10 \mathrm{~B}=0.091 \\
\triangle \mathrm{k} . \text { Reference } \\
\text { Small Core (R SC): } \\
100 \% \text { natural B }= \\
0.029 \Delta \mathrm{k} ; 50 \% \\
\text { natura1 } \mathrm{B}-50 \% 10 \mathrm{~B} \\
=0.056 \Delta \mathrm{k} ; 25 \% \\
\text { natural } \mathrm{B}-75 \% 10 \mathrm{~B} \\
=0.065 \Delta \mathrm{k} .\end{array}$ & $\begin{array}{l}\text { RZC: } 100 \% \text { natural } \\
\text { B = } 0.005 \triangle \mathrm{k} ; \\
75 \%-25 \%=0.00075 \\
\Delta \mathrm{k} ; 50 \%-50 \%= \\
0.0114 \Delta \mathrm{k} . \quad \mathrm{RSC}: \\
100 \%=0.0036 \triangle \mathrm{k} ; \\
50 \%-50 \%=0.007 \\
\Delta \mathrm{k} ; 25 \%-75 \%= \\
0.0081 \Delta \mathrm{k} .\end{array}$ & \\
\hline EBR-I ${ }^{(7)}$ & $\begin{array}{l}\text { Fast breeder, } \\
\text { Na-cooled }\end{array}$ & $\begin{array}{l}12 \text { vertical SS-clad } \\
\text { natural uranium rods- } \\
8 \text { serve as safety, } \\
4 \text { as fine control; } \\
\text { entire outer blanket }(\mathrm{Pb}) \\
\text { or cup is raised or } \\
\text { lowered rel. to core, } \\
\text { hydraulically; tapered } \\
\text { uranium safety plug- } \\
\text { must be fully inserted } \\
\text { before outer blanket can } \\
\text { be raised to a critical } \\
\text { position-pneumatically } \\
\text { driven. }\end{array}$ & $\begin{array}{l}\text { Pb cup: } 5.25 \% \\
\Delta \mathrm{k} / \mathrm{k} ; \text { safety rods: } \\
0.18 \% \Delta \mathrm{k} / \mathrm{k} \text {; safety } \\
\text { plug: } 0.06 \% \Delta \mathrm{k} / \mathrm{k} . \\
\text { Total: } 5.49 \% \\
\Delta \mathrm{k} / \mathrm{k} .\end{array}$ & $\begin{array}{l}\text { Safety rod: } 0.028 \% \\
\Delta \mathrm{k} / \mathrm{k} .\end{array}$ & 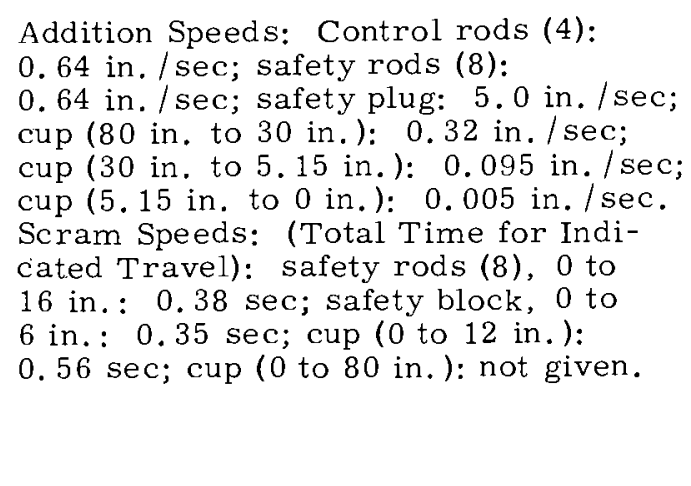 \\
\hline
\end{tabular}



TABLE I. A. CONTROL AND SAFETY SYSTEMS (contd)

\begin{tabular}{|c|c|c|c|c|c|}
\hline EBR-II ${ }^{(9)}$ & $\begin{array}{l}\text { Fast breeder } \\
\text { Na-cooled }\end{array}$ & $\begin{array}{l}12 \text { control rods (fail- } \\
\text { safe); } 2 \text { safety rods; } \\
\text { vertically operating; } \\
\text { consist of modified } \\
\text { movable fuel subassem- } \\
\text { blies with Na "voids." }\end{array}$ & $\begin{array}{l}0.06 \Delta \mathrm{k} / \mathrm{k}(12 \\
\text { control) }) 0.015- \\
0.020 \Delta \mathrm{k} / \mathrm{k}(2 \\
\text { safety } \operatorname{rods}) .\end{array}$ & $\begin{array}{l}\text { Control: }<0.006 \\
\Delta \mathrm{k} / \mathrm{k} ; \text { Safety: } \approx \\
0.0075 \Delta \mathrm{k} / \mathrm{k} .\end{array}$ & $\begin{array}{l}\text { Normal operation limit: } 5 \text { in. } / \mathrm{min} \\
\text { Safety rod: } 2 \mathrm{in.} / \mathrm{min} .\end{array}$ \\
\hline $\mathrm{ZPR}-\mathrm{III}(10,11)$ & $\begin{array}{l}\text { Fast, A1-simulated } \\
\text { coolant; split- } \\
\text { table machine }\end{array}$ & $\begin{array}{l}10 \text { control-safety rods } \\
\text { (horizontal) of fission- } \\
\text { able material, } 5 \text { for } \\
\text { each core half. Maxi- } \\
\text { mum worth when fully } \\
\text { inserted. Each rod } \\
\text { has } 1 / 4 \text { HP, reversible } \\
\text { gear head motor with } \\
\text { break, driving a pinion } \\
\text { through a magnetic } \\
\text { clutch. All rods pulled } \\
\text { out of core by air pres- } \\
\text { sure during scram. } \\
\text { The } 2 \text { core halves are } \\
\text { also moved apart at a } \\
\text { speed of } 30 \text { in./min dur- } \\
\text { ing scram reducing re- } \\
\text { activity at a rate of } \\
2-1 / 2 \% / \text { sec. } 8 \text { safety } \\
\text { rods are driven in be- } \\
\text { fore startup; } 2 \text { rods } \\
\text { serve control function. }\end{array}$ & Rods: $8 \% \Delta \mathrm{k} / \mathrm{k}$ & $\begin{array}{l}\text { Maximum of } 1 \% \\
\Delta \mathrm{k} / \mathrm{k} \text { each (or } \\
0.0015 \Delta \mathrm{k} / \mathrm{k}-\text { in. ) } \\
0.002 \Delta \mathrm{k} / \mathrm{k}-\mathrm{in} . \\
\text { for Pu loading. }\end{array}$ & $\begin{array}{l}\text { Limited to } 4 \mathrm{in} . / \mathrm{min}(0.07 \mathrm{in.} / \mathrm{sec}) \\
\text { with } 10 \mathrm{in.} \text { total travel. }\end{array}$ \\
\hline
\end{tabular}



TABLE I. A. CONTROL AND SAFETY SYSTEMS (contd)

\begin{tabular}{|c|c|c|c|}
\hline$\underline{\text { Name }}$ & $\begin{array}{c}\text { Reactivity } \\
\text { Addition Rate } \\
\end{array}$ & Shutdown Margin & Accidents Considered \\
\hline FERMI & $\begin{array}{l}\text { Safety; } 8 \text { rod rate: } 1 \text { c/sec max. } \\
\text { Control; } 2 \text { rod rate: } \\
1 \text { c/sec max. (1.a) }\end{array}$ & $\begin{array}{l}@ 517^{\circ} \mathrm{F}(\text { startup })=\$ 9.30 \\
@ \text { op. temp. }=\$ 9.90 \mathrm{~g}\end{array}$ & $\begin{array}{l}\text { Stuck safety rod failing to scram; } \\
\text { cont. withdrawal of control (safety) } \\
\text { rods at runaway speed. }(1 . \mathrm{g})\end{array}$ \\
\hline Hallam & $0.03 \% \Delta \mathrm{k} / \mathrm{k}-\mathrm{sec}^{(2 . a)}(19 \operatorname{rod} \mathrm{s})$ & $6 \% \Delta \mathrm{k} / \mathrm{k}(2 . \mathrm{a})$ & $\begin{array}{l}\text { Control rod thimble leak; control } \\
\text { rod withdrawal @ source, low and high } \\
\text { power. }(2 . c)\end{array}$ \\
\hline SEFOR & $\begin{array}{l}\text { Coarse Control Rod Drives--8: } \\
\$ 0.05 / \mathrm{sec} ; \text { Fine Control Rod } \\
\text { Drives: } \$ 0.01 / \mathrm{sec} \text {. }\end{array}$ & $\begin{array}{l}\text { At normal shutdown temp } \\
(350 \mathrm{~F}): \$ 7.4 ; \$ 6.0 \mathrm{with} \\
\text { one rod stuck. }\end{array}$ & $\begin{array}{l}\text { 1) Rod run-in starting at rated power } \\
(20 \mathrm{MW}) \\
\text { 2) Rod run-in from source-level power } \\
\text { ( } 1 \mathrm{~W}) \\
\text { 3) Jamming of reflector rods. }\end{array}$ \\
\hline FARET & $\begin{array}{l}\text { Only rates given are associated } \\
\text { with credible accidents; } \$ 20 / \\
\text { sec max. for each core type. }\end{array}$ & & $\begin{array}{l}\text { Unplanned removal of control rod: } \\
\text { a. Malfunction of control rod drives* } \\
\text { b. Malfunction of fuel-handling machine* } \\
\text { c. By manual means: max. withdrawal } \\
\text { rate by } 2 \text { men: } 3.3 \text { in. } / 45 \text { msec or } \approx \\
6 \mathrm{ft} / \mathrm{sec} \text {. *Both are rate limited } \\
\text { so that excessive reactivity cannot } \\
\text { be inserted by erroneous actions. }\end{array}$ \\
\hline EBR-I & $\begin{array}{l}\text { Control rods } 4: 1.1 \times 10^{-5} \\
\Delta \mathrm{k} / \mathrm{k}-\mathrm{sec} \text { per } \mathrm{rod} \text {; safety rods- } \\
8: 1.1 \times 10^{-5} \Delta \mathrm{k} / \mathrm{k}-\mathrm{sec} \text { per } \\
\text { rod; safety plug: } 4.9 \times 10^{-4} \\
\Delta \mathrm{k} / \mathrm{k}-\mathrm{sec} \text {; cup ( } 80 \text { in. to } 30 \mathrm{in} \text { ) }) \\
\text { not given; cup }(30 \mathrm{in} \text {. to } 5.15 \\
\text { in.): } 3.75 \mathrm{x} 10^{-4} \Delta \mathrm{k} / \mathrm{k}-\mathrm{sec} \text {; cup } \\
(5.15 \text { in. to } 0 \text { in. }): 1.54 \times 10^{-5} \\
\Delta \mathrm{k} / \mathrm{k} \text { sec. }\end{array}$ & & $\begin{array}{l}\text { Control and safety rod failure-- } \\
\text { simultaneous failure of any or all } \\
\text { considered. }\end{array}$ \\
\hline EBR-II & $\begin{array}{l}\text { Control: }<0.00006 \Delta \mathrm{k} / \mathrm{k}-\mathrm{sec} \\
\text { per rod; Safety: }<0.0001 \Delta \mathrm{k} / \mathrm{k} \text { sec } \\
\text { per rod; max. rate based on } 2 \text { rods: } \\
<0.00011 \Delta \mathrm{k} / \mathrm{k}-\mathrm{sec} \text {. }\end{array}$ & $0.05 \Delta \mathrm{k} / \mathrm{k} @$ operating temp & $\begin{array}{l}\text { Safety rod run-in (both); single } \\
\text { control rod run-in. }\end{array}$ \\
\hline ZPR-III & $\begin{array}{l}\Delta \mathrm{k} / \Delta \mathrm{t} \leq 5 \times 10^{-4} / \mathrm{sec} \text { for } 235 \mathrm{U} \\
\Delta \mathrm{k} / \Delta \mathrm{t}=1.6 \times 10^{-4} / \mathrm{sec} \text { for } \mathrm{Pu}\end{array}$ & & $\begin{array}{l}\text { Loss of electrical power resulting } \\
\text { in de-energizing of electromagnetic } \\
\text { clutches and stopping of drives. }\end{array}$ \\
\hline
\end{tabular}



TABLE I. B, REACTOR PROTECTION SYSTEMS

$\underline{\text { Name }}$

\begin{tabular}{lc}
$\frac{\text { Name }}{\text { FERMI }}$ & Safety $\operatorname{rod} \operatorname{drop}(1 . a)$ \\
\hline Hallam & Safety $\operatorname{rod} \operatorname{drop}(2 . a)$
\end{tabular}

Neutron Flux Channels

2 channels--source range (shutdown to $12 \mathrm{~kW}$ ); (either channel scrams); 3 channels--intermediate range (1. $2 \mathrm{~kW}$ to $1200 \mathrm{MW}$ ); (2 out of 3 channels initiate scram); 6 channels--power range $(2 \mathrm{MW}$ to $300 \mathrm{MW}$ on 5 of 6 channels; $14-1400 \mathrm{MW}$ on 6 th); (2 out of 3 channels initiate scram) (1.b)

I and II--source range channels $\left(6 \times 10^{-9}\right.$ to $6 \times 10^{-4} \%$
rated power); III and IV--in intermediate range ( $6 \times 10^{-5}$ to $10 \%$ rated power); V, VI and VII--power range protective system; VIII, IX--identical to V, range protective system; VIII, $\mathrm{X}$ and VII--provided for plant control $(0.1$ to $150 \%$
VI rated power). (2.a)

\begin{tabular}{|c|c|c|}
\hline SEFOR & Inconel reflector dropped & $\begin{array}{l}\text { 1) "Source Range" or Startup: } 2 \text { channels } \\
\text { 2) "Intermediate Range": } 2 \text { channels } \\
\text { 3) "Wide Range": } 3 \text { channels }\end{array}$ \\
\hline
\end{tabular}

3) "Wide Range": 3 channels

FARET 8 control rod assemblies

11 detector channels for: (2 out of 3 channels initiate scram)

1) monitoring and indicating neutron flux at all powers from source level to $300 \%$ of full power;

2) protecting against short reactor periods during startup and normal operation, and against excessive power levels;

3) generating a signal necessary for automatic control of reactor flux level.

EBR-I 8 safety rods driven from cup;

3 flux level trip circuits ( 1 on standby; either of the other 2 initiate scram); 2 period circuits; vibrating reed electrometer (startup); startup counter; galvanometer and automatic control

EBR-II 12 fuel-bearing control rods

Startup Range: 2 identical fission counter channels (1 and 2) (either will initiate scram); Log Power Range: Channels 3 and 4 are logarithmic level channels employing measurement of current from ionization chambers (either will initiate scram); Linear Power Range; Channels 5 and 6 are linear wide-range dc amplifier channels which measure current from ionization chambers (either will initiate scram); Channels $7,8,9$, and 10 are identical in range and employ dc amplifiers which measure current from ionization chambers ( 2 out of 4 produce scram).

\begin{tabular}{lll}
\hline ZPR-III & 1) 2 linear electrometer circuits \\
separation of core halves & 2) gamma log amplifier circuit \\
& 3) 2 proportional counter circuits \\
& 4) 3 trip level safety circuits \\
& 5) 2 period meter circuits
\end{tabular}



TABLE I. B. REACTOR PROTFCTION SYSTFMS (rontd)

\begin{tabular}{|c|c|}
\hline Name & Trips (Scram) \\
\hline FERMI & $\begin{array}{l}\text { 1) High power lavel } \\
\text { 2) Excessive rate of power decrease } \\
\text { 3) Short period } \\
\text { 4) High Na temp } \\
\text { 5) Na flow ( } 2 \text { out of } 3 \text { cooling circuits): } 75 \% \\
\text { 6) } 10 \text { sec period or less (source range channels) } \\
\text { 7) } 20 \text { sec period or less (intermediate channels) } \\
\text { 8) Failure of one primary loop and secondary loop in another circuit } \\
\text { 9) Loss of } 28 \text { V dc supply. (1.b) }\end{array}$ \\
\hline Hallam & $\begin{array}{l}\text { 1) *High computed outlet temp (includes high neutron flux, low } \\
\text { Na flow, and high inlet temp) } \\
\text { 2) *High } \mathrm{Na} \text { temp at fuel channel outlet } \\
\text { 3) * High rate of change } \mathrm{Na} \text { temp at fuel channel outlet } \\
\text { 4) * Low reactor } \mathrm{Na} \text { level } \\
\text { 5) Loss of power to any main } \mathrm{Na} \text { pump } \\
\text { 6) * Low boiler } \mathrm{H}_{2} 0 \text { level in any Na circuit } \\
\text { 7) } * \text { High or low primary to secondary flow ratio in any } \\
\text { Na circuit. }(2 \text { a) } \\
\text { *Coincidence circuits (either } 1 \text { or } 2 \text { out of } 3 \text { ) }\end{array}$ \\
\hline SEFOR & $\begin{array}{l}\text { 1) Scram producing conditions } \\
\text { a. High neutron flux ( } 1 \text { out of } 3 \text { ) } \\
\text { b. High-low neutron flux (scale indications) (2 out of } 3 \text { ) } \\
\text { c. Short period ( } 1 \text { out of } 2 \text { ) } \\
\text { d. High seismic activity } \\
\text { e. Electrical power loss } \\
\text { f. Low reactor Na level } \\
\text { g. Very low reactor Na level } \\
\text { h. High temp reactor Na } \\
\text { i. Low flow main primary loop } \\
\text { j. Low flow main secondary loop } \\
\text { k. Low level secondary expansion tank } \\
\text { l. Low pressure secondary expansion tank } \\
\text { m. High temp main secondary cold leg } \\
\text { n. High reflector temp } \\
\text { o. High temp main primary pump winding (incl.power supply shutoff) } \\
\text { p. Main load center electrical power loss } \\
\text { 2) Automatic rundown conditions } \\
\text { a. Low neutron flux } \\
\text { b. High level secondary expansion tank } \\
\text { 3) Ventilation valve isolation } \\
\text { a. High radiation ventilation exhaust }\end{array}$ \\
\hline
\end{tabular}



TABLE I. B. REACTOR PROTECTION SYSTEMS (contd)

FARET

EBR -I
1) With alarm:

a. Source flux level--low

b. Log count-rate level--high

c. Log count-rate period--short/detector voltage--low

d. Log $\mathrm{N}$-period--short/detector voltage--low

e. Automatic flux control rod down

g. Power range above fixed level/above automatic flow set

level/detector voltage--low

h. Any control rod unlatched

i. Any control rod not "full down"

1. Any control rod not full down

. Control rod scram assist pressur

1. Reactor inlet coolant flow rate of change--high

m. Reactor outlet coolant temp--high

n. Reactor outlet temp rate of change--high

n. Reactor outlet temp rate of change--hig

p. Secondary pump motor power

$r$. Main secondary heat exchanger power interruption

r. Main secondary heat exchanger pow

t. Reactor blanket gas pressure--high

u. Cell isolation trip (access lock open)

v. Earthquake detection

w. Manual scram

2) Alarm only:

a. Linear level range setting interlock

b. Main primary-secondary flow ratio--high/low

c. Primary/secondary pump clutch temp--high

d. Cell gamma radiation--high

e. Cell atmosphere temp--high

f. Cell differential pressure--high

g. Smoke in cell, cavity, or vault

1) Short negative period-- 2 channels

2) Short positive period-- 2 channels

3) Reactor coolant flow--low

4) Reactor inlet temperature--high

5) Reactor outlet temperature--high

6) Heat exchanger outlet temperature--high

Fuel rod temperature--high

8) Elevator leaves stops

10) Gravity tank drain valve open

11) Reactor overflow valve closed

2) Receiving tank overflow valve closed

3) High neutron flux-- 2 channels

4) Blanket rod temperature--high

15) Reactor assembly inlet valves (all internal valves not completely up or down)

16) Reactor assembly throttle valves (both internal valves not in correct position for series or parallel flow)

17) Compressed air supply to valve operators--low

2-Minute Delayed Shutdown Trips

1) Pumped coolant flow low

) Circulating gas flow low

Elevator hydraulic pressure low

Automatic control exceeds set point

5) Outer blanket cooling air (low flow)

In addition, 28 interlocks produce "alarm only. " 

EBR-II
Safety trip provisions: a single period trip causes scram at any power level; a single high-level trip causes scram at levels up to about $50 \%$ power; 2 high-level trips (out of 4 ) cause scram in high power range.

Scram (with alarm):

1) Period too short

2) Power level, based on neutron flux level, too high

3) Loss of power to either main pump

4) Core inlet coolant flow rate too low

5) Blanket inlet coolant flow rate too low

6) Total reactor coolant flow rate, measured at reactor outlet, too low

7) Reactor tank cover unlocked

8) Coolant mean temp in reactor upper plenum too high

9) Coolant temp at selected reactor subassembly outlets too high

10) Coolant pressure in reactor upper plenum too high or too low

11) Temp differential between HX outlet $\mathrm{Na}$ and primary tank bulk $\mathrm{Na}$ too high

12) Primary tank bulk $\mathrm{Na}$ temp too high or too low

13) Primary tank bulk $\mathrm{Na}$ level too high or too low

14) Primary tank inert blanket gas pressure too high

15) Smoke in Reactor Plant

In addition, 106 other conditions will produce "Alarm Only."

1) Scram Interlocks:

a) Source leaves assembly

b) Carriage retracts from closed position after having reached that position

c) Airlock door opens or personnel counter indicates other than zero

d) High power level ( 3 circuits)

e) Short period ( 2 circuits)

f) Low safety rod drive air pressure

g) Air pressure becomes positive (gage) in assembly room

h) Loss of high-voltage supply to period and power-level circuits (loss of line voltage also scrams these circuits)

2) Start Up Interlocks--reactor control console cannot be reset for startup under any of following conditions:

a) Carriage is not fully retracted

b) Personnel counter is not at zero or the airlock doors not closed

c) Low safety rod drive air pressure

d) Air pressure in assembly room is not negative (gage)

e) All period and power level trip circuits not reset

3) Carriage Drive Interlocks--before carriage can be started:

a) Loading platform must be out

b) Control console must be reset

c) Both neutron sources must be in reactor

d) Neutron detection instrument must indicate neutrons are present 

TABLE II. BACKUP SYSTEMIS

\begin{tabular}{|c|c|c|c|c|c|}
\hline \multirow[t]{2}{*}{ Name } & \multirow[t]{2}{*}{$\underline{\text { Secondary Shutdown }}$} & \multicolumn{2}{|c|}{ Coolant System Backup } & \multicolumn{2}{|c|}{ Electrical Power System } \\
\hline & & Decay Heat Removal System & Loss of Coolant Protection & Primary Sources & Emergency Sources \\
\hline FERMI ${ }^{(1)}$ & None & $\begin{array}{l}\text { Natural circulation. } 3 \text { inde- } \\
\text { pendent circuits for each of } \\
\text { primary and secondary cool- } \\
\text { ant systems. (1.b) }\end{array}$ & $\begin{array}{l}\text { 1) Secondary containment } \\
\text { 2) Siphon breakers } \\
\text { 3) No drains in primary } \\
\text { system } \\
\text { 4) Reserve Na supply(1.b) }\end{array}$ & $\begin{array}{l}2 \text { separate } 120 \mathrm{kV} \\
\text { transmission lines; } \\
4800 \mathrm{~V} \text { supply } \\
\text { through } 2,600 \mathrm{kVA} \\
\text { step down trans- } \\
\text { formers. } 4 \text { sep- } \\
\text { arate } 480 \mathrm{~V} \text { dis- } \\
\text { tribution busses. }(1 . \mathrm{b})\end{array}$ & $\begin{array}{l}\text { Diese1 gen. } 250 \mathrm{~kW} @ \\
480 \mathrm{~V} . \text { Battery power: } \\
125 \mathrm{~V} \text { with dc generator. } \\
\text { One } 6000 \mathrm{kVA} \text { trans- } \\
\text { former on } \operatorname{standby}(1 . \mathrm{b})\end{array}$ \\
\hline Hallam ${ }^{(2)}$ & None & $\begin{array}{l}3 \text { independent circuits-- } \\
\text { natural circulation or by } \\
\text { pump. }(2 . \mathrm{a}, \mathrm{c})\end{array}$ & $\begin{array}{l}\text { Na heat transfer piping } \\
\text { within reactor cavity enclosed } \\
\text { in guard piping. Outside } \\
\text { cavity: steel-1ined pipe tun- } \\
\text { nels and heat exchangers. } \\
\text { (2.c) }\end{array}$ & $\begin{array}{l}\text { Normal station trans- } \\
\text { former: } 4160 \mathrm{~V}, 3 \Phi \\
60 \text { cycle. Reserve } \\
\text { station (startug) } \\
\text { transformer. (2.a) }\end{array}$ & $\begin{array}{l}500 \mathrm{kVA} \text { diesel-generator; } \\
\text { battery power.(2.a) }\end{array}$ \\
\hline SEFOR ${ }^{(5)}$ & None & $\begin{array}{l}\text { Natural convection or an } \\
\text { auxiliary coolant system. }\end{array}$ & $\begin{array}{l}\text { 1) Siphon breaker } \\
\text { 2) Auxiliary system } \\
\text { 3) Check valve } \\
\text { 4) Turning off of pumps } \\
\text { (low level trip) } \\
\text { 5) Safety vessel in cup form } \\
\text { around reactor vessel. }\end{array}$ & $\begin{array}{l}\text { Local utility; } 69 \mathrm{kV} \\
(3 \Phi) \text { transmission } \\
\text { line. }\end{array}$ & $\begin{array}{l}400 \mathrm{~kW} \text { diesel-driven } \\
\text { generator output for at } \\
\text { least } 8 \text { hours. } 3 \text { battery } \\
\text { system } \mathrm{s} \text {. }\end{array}$ \\
\hline FARET (6) & None & $\begin{array}{l}\text { Auxiliary coolant system } \\
\text { designed to remove about } \\
3 \text { MW of heat by forced } \\
\text { circulation; operating in } \\
\text { parallel with main coolant } \\
\text { system; primary loop cool- } \\
\text { ant--Na; secondary loop } \\
\text { coolant--NaK. }\end{array}$ & $\begin{array}{l}\text { Outer reactor vessel wall } \\
\text { designed to sustain Na load } \\
\text { in event of failure of inner } \\
\text { vessel wall. Void space in } \\
\text { cavity is large compared to } \\
\text { volume of Na above core in } \\
\text { reactor vessel--in the unlikely } \\
\text { event that both walls of vessel } \\
\text { are violated simultaneously } \\
\text { below core level, loss of cool- } \\
\text { ant from core could occur. } \\
\text { Reactor vessel and critical } \\
\text { piping leading from cavity to } \\
\text { process systems in vault will } \\
\text { be of double-walled } \\
\text { construction. }\end{array}$ & $\begin{array}{l}\text { Single-circuit } 13.8 \\
\mathrm{kV} \text { pole lines orig- } \\
\text { inating from EBR-II } \\
\text { area. Either line } \\
\text { capable of supply- } \\
\text { ing full FARET load } \\
\text { upon failure of other. }\end{array}$ & $\begin{array}{l}\text { 1) Automatic transfer of } \\
480 \mathrm{~V} \text { motor control center } \\
\text { to source of emergency } \\
\text { power upon loss of normal } \\
\text { utility power: one quick } \\
\text { starting diesel generator } \\
\text { set (cont. operation for } \\
48 \mathrm{hr} \text { ). } \\
\text { 2) } 120 \mathrm{~V} \text { ac cont, power } \\
\text { load center supplied by } \\
3 \text {-machine, ac motor, dc } \\
\text { motor generator set and } \\
125 \mathrm{~V} \text {, dc battery. } \\
\text { 3) Battery powered, } 125 \mathrm{~V} \\
\text { dc load center with motor- } \\
\text { driven charger on battery } \\
\text { sized to carry cont. } 125 \mathrm{~V} \\
\text { dc load. } \\
\text { 4) Portable battery- } \\
\text { powered lighting units at } \\
\text { all exits and occupied } \\
\text { areas. }\end{array}$ \\
\hline
\end{tabular}



TABLE II. BACKUP SY STEMS (contd)

\begin{tabular}{|c|c|c|c|c|c|}
\hline $\mathrm{EBR}-\mathrm{I}(7)$ & None & $\begin{array}{l}\text { Gravity supply tank } \\
(2700 \text { gal cap.) provides } \\
\text { about } 9 \text { min of full } \\
\text { coolant flow in event of } \\
\text { primary pump failure. } \\
\text { (2 min delayed shutdown } \\
\text { assures most of tank cap. } \\
\text { available for cooling). } \\
\text { Throttling provides up to } \\
8 \text { hr of flow at sufficient } \\
\text { rate to remove decay } \\
\text { heat. } \\
\text { A separate completely } \\
\text { independent convection } \\
\text { loop cooling system; } \\
\text { heat is removed from } \\
\text { loop coolant by means of } \\
\text { a finned-tube NaK-to-air } \\
\text { heat exchanger--although } \\
\text { fan equipped, natural } \\
\text { convection is sufficient } \\
\text { for adequate heat removal. }\end{array}$ & $\begin{array}{l}\text { All valves in coolant systems } \\
\text { have welded double-bellows } \\
\text { seals. Tandem arrange- } \\
\text { ment of double-bellows means } \\
\text { both must fail to cause coolant } \\
\text { leak to atmosphere. All cells } \\
\text { containing primary-system } \\
\text { component are equipped with } \\
\text { steel-lined floors with curbs } \\
\text { sufficiently high to contain } \\
\text { any leakage. If necessary } \\
\text { (in case of leakage in primary- } \\
\text { system components), the } \\
\text { entire inventory of NaK may } \\
\text { be rapidly drained into tanks } \\
\text { located in lowest cells--except } \\
\text { NaK in reactor and primary } \\
\text { convection loops cannot be } \\
\text { drained ( guarantees reactor } \\
\text { cooling will always be avail- } \\
\text { able for removal of decay } \\
\text { heat). Reactor tank is } \\
\text { double-walled and under little } \\
\text { stress. }\end{array}$ & & $\begin{array}{l}\text { A diesel-driven } 250 \mathrm{~kW} \\
\text { generator, which responds } \\
\text { to power failure and assumes } \\
\text { reactor building load within } \\
30 \text { sec; a much smaller unit } \\
\text { provides power for emer- } \\
\text { gency lighting. Both respond } \\
\text { automatically to local utility } \\
\text { power outage. Building also } \\
\text { equipped with small battery- } \\
\text { operated lighting units at } \\
\text { strategic control and exit } \\
\text { points. }\end{array}$ \\
\hline EBR-II $(9)$ & None & $\begin{array}{l}\text { After shutdown: coolant flow } \\
\text { is maintained through reactor } \\
\text { by any one of: (a) Operation } \\
\text { of one or both main pumps; } \\
\text { (b) Operation of auxiliary } \\
\text { pump; (c) Natural convection } \\
\text { flow. Heat removal from Na } \\
\text { leaving reactor can be accom- } \\
\text { plished by any of: (a) Heat } \\
\text { can be transferred to secon- } \\
\text { dary system; (b) Heat can be } \\
\text { transferred to bulk Na in } \\
\text { primary tank and then removed } \\
\text { by "shutdown coolers." }\end{array}$ & $\begin{array}{l}\text { The reactor and the entire } \\
\text { primary coolant system, } \\
\text { including HX, are contained } \\
\text { in a large vessel (primary } \\
\text { tank) and operate completely } \\
\text { submerged in the coolant. } \\
\text { Primary tank is double- } \\
\text { walled, right circular cyl- } \\
\text { inder. No external connec- } \\
\text { tions below the liquid Na } \\
\text { level are permitted. The } \\
\text { need for leak tightness of } \\
\text { the primary coolant system } \\
\text { piping is eliminated. Siphon- } \\
\text { ing of primary tank is pre- } \\
\text { vented by incorporation of } \\
\text { surge tank in cold trap inlet } \\
\text { line. }\end{array}$ & $\begin{array}{l}2 \text { full capacity ties } \\
\text { to NRTS } 138 \mathrm{kV} \text { power } \\
\text { loop. When in opera- } \\
\text { tion: the EBR-II } 13.8 \\
\mathrm{kV} \text { generator. (The } \\
2400 \mathrm{~V} \text { and } 480 \mathrm{~V} \text { aux- } \\
\text { iliary power require- } \\
\text { ments are furnished } \\
\text { respectively through } \\
13.8 / 2.4 \mathrm{kV} \text { and } \\
13.8 / 0.48 \mathrm{kV} \text { full } \\
\text { capacity auxiliary } \\
\text { power transformers. }\end{array}$ & $\begin{array}{l}\text { Automatic starting } 480 \mathrm{~V}, \\
3 \Phi, 60 \text { cycle emergency } \\
\text { diesel-generator set; } \\
\text { arranged to operate only } \\
\text { after sustained outage of } \\
\text { the } 3 \text { primary sources ( } 15 \\
\text { to } 20 \text { sec before full power } \\
\text { is reached). Emergency } \\
\text { lighting for entire facility } \\
\text { is supplied from emergency } \\
120 \text { V bus of ac/dc distri- } \\
\text { bution cubicle which is } \\
\text { automatically transferred } \\
\text { to station battery upon } \\
\text { failure of normal ac supply. } \\
\text { Station battery: } 125 \mathrm{~V} \text { with } \\
\text { battery-charging motor- } \\
\text { generator set included for } \\
\text { trickle charging and equal- } \\
\text { izing charging of battery, } \\
\text { and to relieve battery } \\
\text { load during sustained } \\
\text { emergency lighting ser- } \\
\text { vice. During } 15 \text { to } 20 \text { sec } \\
\text { outage battery power is } \\
\text { available for primary } \\
\text { coolant system auxiliary } \\
\text { pump--for } 30 \text { min if } \\
\text { necessary. }\end{array}$ \\
\hline ZPR-III $(10,11)$ & None & & & & \\
\hline
\end{tabular}



TABLE III CONTATNMFNT OR CONFINEMF.NT SYSTFMS

Name

\begin{tabular}{|c|c|}
\hline FERMI ${ }^{(1)}$ & $\begin{array}{l}\text { Reactor Building: cylin- } \\
\text { drical vertical steel vessel } \\
\text { with hemispherical top and } \\
\text { semi-ellipsoidal bottom } \\
\text { head; } 72 \mathrm{ft} \text { diam, } 120 \mathrm{ft} \\
\text { high (51 ft below grade). (1.c) } \\
\text { Reactor vessel: lower, } 114 \\
\text { in, diam, dished elliptical } \\
2 \text { to } 1 \text { bottom head; upper, } \\
\text { cyl., } 174 \text { in. diam with } 115 \\
\text { in. diam rotating plug con- } \\
\text { tainer extension atop it. } \\
\text { (All stainless steel). (1.: a) }\end{array}$ \\
\hline Hallam (2) & $\begin{array}{l}\text { Steel reactor building (no } \\
\text { containment feature): roof } \\
\text { of steel decking; insulated; } \\
\text { steel panel wall exterior } \\
\text { (over steel frame). High } \\
\text { bay area: } 278 \mathrm{ft} \text { long, } 80 \\
\text { ft wide, } 75 \mathrm{ft} \text { high. React or } \\
\text { vessel (Type } 304 \text {. SS) of } \\
\text { welded constr. (2.a) }\end{array}$ \\
\hline SEFOR ${ }^{(5)}$ & $\begin{array}{l}\text { First Containment Bar- } \\
\text { rier (Nitrogen Cells and } \\
\text { Refueling Cell): reactor } \\
\text { cavity, reflector control } \\
\text { drive cell, primary Na } \\
\text { equipment cell, primary } \\
\text { drain tank cell, and refuel- } \\
\text { ing cell above reactor. } \\
\text { Second Containment Bar- }\end{array}$ \\
\hline
\end{tabular}

- Design Basis

Design Basis

Pressure, Temperature, Leakage Rates

Outer steel pressure vessel; steady steady state neg. int. pressure: 2 psig. Design temp: $460{ }^{\circ} \mathrm{F}_{(i . d)}(1 . \mathrm{c})$ Leakage vessel: steady-stat pressure: 50 psig. and temp: $1000{ }^{\circ} \mathrm{F}$. (1.a) Outer steel pressure vessel: designed to withstan an explosion equivalent to $1000 \mathrm{lb}$
During Construction Containment Tests

After Construction

Confinement: Reactor vessel: $30 \mathrm{psig}$ below grid plate, 2 psig (reactor cavity

above plate: allowable leakage rate: $3.4 \times 10^{-3} \mathrm{~cm}^{3} / \mathrm{sec}\left(0.11 \mathrm{ft}^{3} /\right.$ day--from $^{-}$ reactor into building--calculated); reactor cavity; 2 .c) Reactor high.

area--design in-leakage rate: $3120 \mathrm{cfm}$
(a) $-1 / 8 \mathrm{in} . \mathrm{H} 20$ internal pressure.(2,a)

\section{Reactor building penetra- \\ Another overload test} tions--where practical welds were radiographed with soapsuds solution. After leak rate tests, all remaining welds were radiographed, and either magnachecked (1.c) penetrant similar to that durin (1.e)

\begin{tabular}{|c|c|c|}
\hline \multicolumn{3}{|c|}{$\begin{array}{l}\text { First Containment Barrier } \\
\qquad, \mathrm{Cell}\end{array}$} \\
\hline & $\mathrm{N}_{2} \mathrm{Cell}$ & A Cell \\
\hline $\begin{array}{l}\text { Pressure } \\
\text { Desion }\end{array}$ & & \\
\hline $\begin{array}{l}\text { Design, max. psig } \\
\text { Design, min. in. }\end{array}$ & 10 & 10 \\
\hline $\begin{array}{c}\mathrm{H}_{20}{ }^{\circ} \\
\text { Operation, in. } \\
\mathrm{H}_{2} \mathrm{O}\end{array}$ & $\begin{array}{l}-6 \\
1 / 2 \pm 1 / 4\end{array}$ & $\begin{array}{l}-6 \\
1 \pm 1 / 20 \\
-2 \pm 1 *\end{array}$ \\
\hline
\end{tabular}
*If and when the inside of the cell becomes alpha-contaminated.

b. Temperature

Design, max. ${ }^{\circ} \mathrm{F} \quad{ }^{\circ}{ }^{25}$ 250
120

c. Leakage rates--@ 10 psig $<20 \%$ of contained volume over $24 \mathrm{hr}$ period. (Concrete walls are sealed with a lining to minimize gas seepage).

Second Containment Barrier

a. Pressure

2. 30 psis Design, externa :

b. Temperature

1 psig coincident with design internal $0^{\circ} \mathrm{F}$ (co

design internal pressure

c. Leakage rates--2.5\% of contained volume @ 30 psig over a $24 \mathrm{hr}$ period.

$\begin{array}{ll}\text { Second C/B: all welds and } & \text { First C/B: Pneumatically } \\ \text { seams radiographically } & \text { tested; integrated leak } \\ \text { examined; all welds and } & \text { test. Final leakage tests } \\ \text { door gaskets soap-bubble } & \text { on both barriers and peri- } \\ \text { tested for leaks. } & \text { odic tests thereafter. } \\ & \text { Means are to be provided } \\ & \text { for introducing compressed } \\ \text { air into each access lock } \\ \text { and electrical penetration } \\ \text { to test same for leak- } \\ \text { tightness. }\end{array}$



TABLE III. CONT AINMENT OR CONFINEMENT SYSTEMS (contd)

\begin{tabular}{|c|c|c|c|}
\hline FARET $^{(6)}$ & $\begin{array}{l}\text { Reactor building (not a } \\
\text { containment vessel) is con- } \\
\text { ventional structure fabri- } \\
\text { cated of masonry wainscot, } \\
\text { prefabricated metal siding } \\
\text { and built-up roof. (Provides } \\
\text { containment of activated gases } \\
\text { released from reactor con- } \\
\text { finement structure). } \\
\text { Confinement: a) cell; b) } \\
\text { cavity; c) vault. }\end{array}$ & $\begin{array}{l}\text { Confinement structures only: 1) pressure-- } \\
\text { internal static pressure of } 30 \text { psig with over- } \\
\text { load factor of about } 100 \%--60 \text { psig max.; } 2) \\
\text { Temperature--not given; 3) Leakage rates-- } \\
5 \% / \text { day @ } 1 \text { psi differential pressure and } \\
700^{\circ} \mathrm{F} \text { (max. rate). An equivalent explosion } \\
\text { of } 40 \mathrm{lb} \text { TNT (bare charge) at the core would } \\
\text { be confined. }\end{array}$ & \\
\hline$E B R-I(7)$ & $\begin{array}{l}\text { Facility located entirely within } \\
\text { single ordinary building of steel, } \\
\text { concrete, and brick. Building } \\
\text { has maximum height of } 50 \mathrm{ft} \text { and } \\
\text { lowest accessible floor lies } \\
\text { approximately } 25 \mathrm{ft} \text { below grade. } \\
\text { Main body of building covers } \\
\text { area } 922 \text { x } 77 \mathrm{ft} \text {. Building not } \\
\text { designed with any containment } \\
\text { features. Reactor Tank Assem- } \\
\text { bly: a } 7 \text { - Rided polygon in shape; } \\
\text { tank and all piping leading from } \\
\text { it through the shielding are } \\
\text { double-walled. Portion of tank } \\
\text { containing core and inner } \\
\text { blanket is } 28 \text { in. in length and } \\
15.87 \text { in. in ID. Wall of lower } \\
\text { portion of inner reactor loop is } \\
5 / 16 \text { in.thick; outer Inconel tank } \\
\text { with wall thickness of } 1 / 16 \text { in. } \\
\text { serves as emergency receiver } \\
\text { for primary coolant in event of } \\
\text { failure of inner tank. }\end{array}$ & & \\
\hline $\mathrm{EBR}-\mathrm{II}(9)$ & $\begin{array}{l}\text { Primary Containment System: } \\
\text { Cylindrically shaped "pres- } \\
\text { sure vesse1" which surround } \\
\text { primary tank. Building } \\
\text { Containment System: Steel } \\
\text { "building shell" enclosing } \\
\text { entire Reactor Plant. }\end{array}$ & $\begin{array}{l}\text { Primary Containment System: } 75 \text { psig; } \\
\text { capable of withstanding (without rup- } \\
\text { turing) a } 300 \text { lb TNT equivalent energy } \\
\text { release in the core. Building Contain- } \\
\text { ment System: } 24 \text { psig; } 650^{\circ} \mathrm{F} ; \\
1000 \mathrm{ft} / \text { day @ } 20 \text { psig internal } \\
\text { pressure. }\end{array}$ & $\begin{array}{l}\text { Radiographic examina- } \\
\text { tion of } 10 \% \text { of weld } \\
\text { length was made, includ- } \\
\text { ing all weld intersections. } \\
\text { Stress relieving of shell } \\
\text { as a whole was not contem- } \\
\text { plated. Shell was pneu- } \\
\text { matically pressure tested } \\
\text { at } 30 \text { psig. }\end{array}$ \\
\hline $\mathrm{ZPR}-\mathrm{III}(10,11)$ & $\begin{array}{l}\text { High bay assembly room } \\
\text { of reinforced concrete / } \\
\text { one- story section contain- } \\
\text { ing control room, vault, } \\
\text { etc., of concrete block } \\
\text { exterior; vault has rein- } \\
\text { forced concrete walls and } \\
\text { ceiling. Whole building } \\
\text { has concrete slab floor. } \\
\text { Dimensions of assembly } \\
\text { room: } 45-1 / 2 \mathrm{ft} \text { long, } \\
42 \mathrm{ft} \text { wide, } 29-1 / 2 \mathrm{ft} \\
\text { high }(75,000 \mathrm{ft} 3 \text {; ; vault } \\
\text { room: } 29 \mathrm{ft} \text { long, } 26 \mathrm{ft} \\
\text { wide, } 11-1 / 2 \mathrm{ft} \text { high. }\end{array}$ & $\begin{array}{l}\text { Pressure: In a nuclear excursion } \\
\text { building could be ruptured. }\end{array}$ & \\
\hline
\end{tabular}




Shield; (3) Biological Shields: operating floor shield, biological shield out side reactor building; (4) Special Purpose Shields:
primary coolant piping shields, etc.; (5) Shields for Service Buildings.(1.c)

Hallam

Reactor vessel surrounded by thermal shield--2 concentric, carbon-steel cylinders. Reactor outer vessel is carbon-steel tank. Shielding for accessible high bay areas designed to limit radiation to $0.75 \mathrm{mr} / \mathrm{hr}$ (plugs in place) with $7.5 \mathrm{mr} / \mathrm{hr} \mathrm{max}$. in plug
clearance void areas. (2.a)

SEFOR

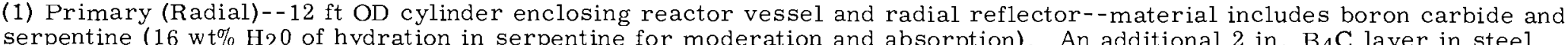
containers surrounds the reflector. Additional serpentine layers: 6 in. and 20.5 in. thicknesses separated by nitrogen coolant gaps (3)

(2) Bottom Shield Plug--combined neutron shield and thermal column in form of cylindrical container filled with serpentine and $\mathrm{B} 4 \mathrm{C}$ (instrumentation plug--flux reading); biological shield (lower section) consists of concrete and steel (gamma shield). (3) Shielding between cells containing radioactive $\mathrm{Na}$ and accessible areas is 4 to $6.5 \mathrm{ft}$ of regular concrete (or equivalent

(4) Radiation Levels: a. $<0.75 \mathrm{mr} / \mathrm{hr}$ in all areas of unrestricted access during reactor operation; $\mathrm{b}$. $<2.5 \mathrm{mr} / \mathrm{hr}$ on operating floor; c. $<10 \mathrm{mr} / \mathrm{hr}$ in areas of restricted access below operating floor; d. $<100 \mathrm{mr} / \mathrm{hr}$ in areas of limited access 2 days after containing $\mathrm{Na}$ of this activity is $3.46 \times 1011 \mathrm{MeV} / \mathrm{cm}^{2}$ - sec. $6.5 \mathrm{ft}$ of regular concrete is sufficient to drop flux level to $8.39 \times 10^{2} \mathrm{MeV} / \mathrm{cm}^{2}-\mathrm{sec}$ or $1.5 \mathrm{mr} / \mathrm{hr}$ (shielding for $\mathrm{Na}$ pipes and tanks).

FARET Reactor vessel to be surrounded by borated-graphite neutron shield. All other shielding details of containment structures not detailed.

EBR -I

Located immediately outside the heavy $\mathrm{Pb}$ outer blanket is an annular layer of graphite, $18 \mathrm{in.}$ thick and $35 \mathrm{in}$. high. On the outside of the graphite is a 4 -in. cast iron course followed by $8-3 / 4 \mathrm{ft}$ of standard concrete. The bottom of the cup is shielded by 4-1/2 ft of steel. The coolant and rod extensions absorb most upward emitted radiations. Two shields atop th reactor further attenuate these radiations; lower shield consists of $2 \mathrm{ft}$ of scrap-filled concrete; upper shield consists of $8 \mathrm{in}$. of iron and masonite laminae. (Both are easily handled by a 20 -ton overhead crane).

EBR-II Neutron Shield: Surrounds the outside of the reactor vessel on all sides and is submerged in bulk Na of primary tank. Shielding
material is graphite and graphite impregnated with $3 \mathrm{wt} \%$ natural B and is canned in SS. Shield is composed of 3 sections: (1) Total graphite thickness of radial neutron shield is 24-3/4 in. of which 8-1/4 in. is borated and 16-1/2 in. is plain graphite; (2) Bottom shield consists of 5 layers (alternate borated and plain graphite) which is $20-5 / 8$ in. thick, of which $12-3 / 8$ in. is carbide with total thickness 24-3/4 in. (3) Top shield contains 6 layers of cans filled with either $3 \%$ borated graphite or boron vessel" surrounding primary tank. constructed of ordinary concrete $6 \mathrm{ft}$ thick, reinforced with continuous hoops of "pressure sile Protection: For protection against missiles, which conceivably could originate within the top closure a missile shield (14 in. thick) of reinforced concrete lines the cylindrical section of building shell from operating floor up, and false ceiling (missile shield) of same construction joins the former and completes enclosure. (Also, a 14 in. thick wall of reinforced concrete or equivalent steel plate thickness is provided for missile protection at personnel air lock opening and freight door opening).

ZPR-III (1) Assembly room: Reinforced concrete; shielding wall between assembly room and control room is $5 \mathrm{ft}$ thick up to $12 \mathrm{ft}$ above
floor and $3 \mathrm{ft}$ thick the remainder of distance to roof. North wall is $2 \mathrm{ft}$ thick, west and south walls $1 \mathrm{ft}$ thick. Partial wall between assembly room and passageway and ventilation equipment mezzanine is $4 \mathrm{ft}$ thick up to $12 \mathrm{ft}$ high and $2 \mathrm{ft}$ thick remainder of distance to rool. Roof has $6 \mathrm{in.}$. Of concrete poured atop cor rugated steel deck.

(3) Reactor: Personnel shield arranged and available if tests in first stages of operation prove it necessary. 

TABLE IV INHERENT REACTIVITY EFFECTS AND IMPORTANT PHYSICS PARAMETERS

\begin{tabular}{|c|c|c|c|c|c|c|}
\hline \multirow{3}{*}{$\frac{\text { Name }}{\text { FERMI }^{(1)}}$} & \multicolumn{2}{|c|}{ Temperature Coefficients } & \multirow{3}{*}{$\begin{array}{l}\text { Coolant/Moderator } \\
\text { Void Coefficient }\end{array}$} & \multirow{3}{*}{$\begin{array}{l}\text { Doppler Effect } \\
\begin{array}{l}-2.59 \text { to }-2.47 \\
\times 10^{-6} \Delta \mathrm{k} / \mathrm{k}^{-}{ }^{\circ} \mathrm{C}(1 . \mathrm{a})\end{array}\end{array}$} & \multicolumn{2}{|c|}{ Kinetics Parameters } \\
\hline & Fuel & Moderator & & & Neutron Lifetime (1) & Delayed Neutron Fraction $(\beta), \Delta \mathrm{k} / \mathrm{k}$ \\
\hline & $\begin{array}{l}-6.16 \times 10^{-6} \\
4 \mathrm{k} / \mathrm{k}-{ }^{\circ} \mathrm{C}(1 . \mathrm{a})\end{array}$ & & & & $1.4 \times 10^{-7} \sec ^{(1 . a)}$ & Effective: 0.0066 (1.a) \\
\hline Hallam $(2)$ & $-1.85 \times 10^{-5} /{ }^{\circ} \mathrm{F}(2 . \mathrm{f})$ & $1.55 \times 10^{-5} /{ }^{\circ} \mathrm{F}^{(2 . \mathrm{f})}$ & & $\begin{array}{l}1.5 \times 10^{-4} /{ }^{\circ} \mathrm{C} \\
\left(0.83 \times 10^{-4} /{ }^{\circ} \mathrm{F}\right)(2 . \mathrm{f})\end{array}$ & $2.8 \times 10^{-4} \mathrm{sec}^{(2 . \mathrm{c})}$ & $0.0069^{(2 . c)}$ \\
\hline SEFOR(5) & $\begin{array}{l}\text { Total: } \\
-4.8 \times 10^{-6} \\
\Delta \mathrm{k} / \mathrm{k}-{ }^{\circ} \mathrm{C}\end{array}$ & & & 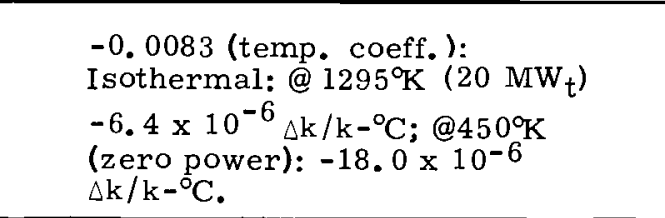 & $0.36 \times 10^{-6} \mathrm{sec}$ & Effective: 0.0033 \\
\hline FARET $(6)$ & 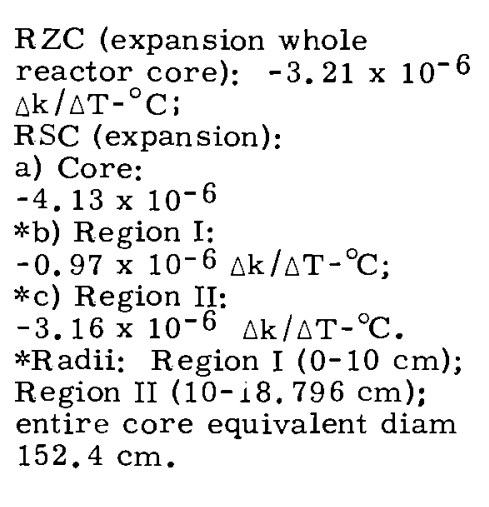 & & & 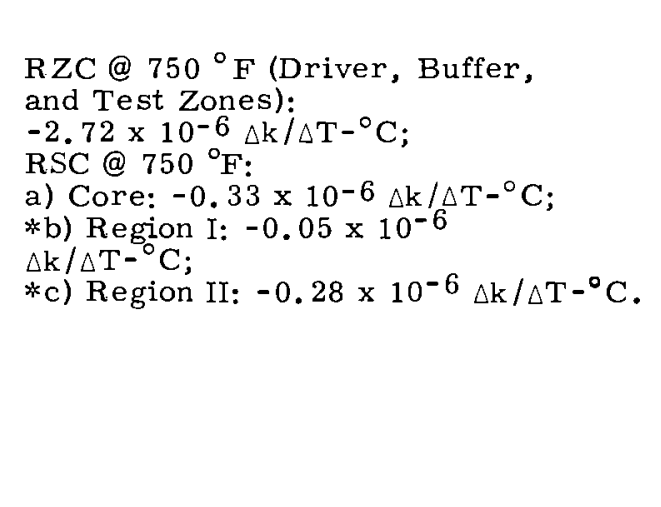 & $\begin{array}{l}\text { Prompt: } \\
\text { a) RZC: } 8.90 \times 10^{-7} \mathrm{sec} \\
\text { b) RSC: } 6.55 \times 10^{-7} \mathrm{sec}\end{array}$ & \\
\hline EBR $-I(7)$ & $>-3.01 \times 10^{-6} \Delta \mathrm{k} / \mathrm{k}-{ }^{-0} \mathrm{C}$ & & & $<0.5 \times 10^{-6} \Delta \mathrm{k} / \mathrm{k}-{ }^{\circ} \mathrm{C}$ & $\begin{array}{l}\text { Prompt: } \\
\text { 4. } \times 10^{-8} \mathrm{sec}\end{array}$ & 0.00296 \\
\hline EBR-II $(9)$ & $-3.6 \times 10^{-5} \Delta \mathrm{k} / \mathrm{k}-{ }^{\circ} \mathrm{C}$ & & & $\begin{array}{l}(\text { Avg): } \\
\Delta \mathrm{k} / \mathrm{k}^{-}{ }^{\circ} \mathrm{C}\end{array}$ & $\begin{array}{l}\text { Prompt: } \\
8 \times 10^{-8} \mathrm{sec}\end{array}$ & \\
\hline ZPR-III $(10,11)$ & & & & $\begin{array}{l}\text { Maximum: } 5 \times 10^{-6} \Delta \mathrm{k} /{ }^{\circ} \mathrm{C} \text { at room } \\
\text { temp. (Pu-C fuel); integrated } \\
\text { Dopplere effect from room temp. } \\
\text { to vaporization would amount to } \\
0.0026 \text { to } 0.004 \Delta \mathrm{k} . \\
+50 . \times 10^{-6} /{ }^{\circ} \mathrm{K} \text { (U fuel). }\end{array}$ & $\approx 10^{-9} \mathrm{sec}$ & $\begin{array}{l}\mathrm{a}^{239} \mathrm{Pu} \text { loadings: . 0022; } \\
\text { b. }{ }^{235} \text { U loadings: . } 00699\end{array}$ \\
\hline
\end{tabular}



TABLE V. FUEL AND FUEL HANDIING
Name FERMI ${ }^{(1)}$
Type of Fuel

1) Core Region: U$10 \mathrm{wt} \%$ Mo; $0.35 \mathrm{wt} \%$ , 2) Axial Blanket Region: U-3 wt\% i) 3) Radial Blank Region: $\mathrm{U}-3$ wto Mo;
0.35 wt $\% 35 \mathrm{U}$ (1.a)
Quantity and Size of Fuel Elements

1) Core Section: 140 pins per subassembly with 105 subassemblies; round pin, U diam 0.148 in., U length, 30.5 in.; 2) Axial assembly with 210 subassemblies; U diam, assembly with 210 subassemblies; U diam .395 in., U length, 14 in.; 3) Inner and rods per subassembly with 531 subas blies; U diam, 0.395 in., U length, 61.75 in. blies; U diam, 0.395 in., U length, 61.75 in subassembly dimensions for all sections. 2.646 in. wall thickness, 0.096 in $(1 . a)$
Charge and Discharge Methods

New fuel is transferred from storage by means the reactor vessel through an exit port. Exchange of subassemblies between transfer the rotating shield plug and offset handling the rotating shield plug and offset handing mechanism. Removal of spent subassemblies of transfer cask car. From cask car, subassemblies are deposited in transfer rotor of $\begin{array}{ll}\text { Hallam } & (2) \quad \begin{array}{l}\mathrm{U}-10 \mathrm{wt} \% \text { Mo alloy; } \\ \end{array} \\ & 3.6 \mathrm{wt} \% 235 \mathrm{U} .(2 . \mathrm{a})\end{array}$
137 elements (18 rod cluster); $224 \mathrm{~kg}$ (U-Mo)/ element and $30,700 \mathrm{~kg}$ U-Mo alloy (total) of which $27,600 \mathrm{~kg}$ is $U$. Size of rods: $0.590 \mathrm{in}$ diam, 3 to $12 \mathrm{in}$. long in Type 304 SS tube. Total active fuel length: $13.5 \mathrm{ft}$. Tube: 0.660 in Total $x 0.010$ in wall thickness $\times 18 \mathrm{ft}$ long. (2.a)
Fuel handling machine consists of a shielded cylinder with two internal hoists and grapple mechanisms to raise and lower core components. Machine supported and transported Maximum which rides on a gantry crane. system provided for fuel system provided for fuel element in machine.

Refueling cell facility (concrete and steel) situated over reactor vessel-part of containvides the primary means of transporting vides the primary means of transporting objects about the refueling cell. Crane: 5 -ton capacity drum hoist on double-bridge-mounted manipulations of crane are made by remote mipulations of crane. ( 1 in diam, material--Type 316 SS.
FARET $^{(6)}$

(hexagonal subassemblies); R ZC: a) Test Zone: $(\mathrm{Pu}-\mathrm{U}) \mathrm{O}_{2}, 238 \mathrm{U}$ enrich. 1239 . 239 ; (2) b) Buffer Zone: deplet $\mathrm{UO}_{2} ; 23 \%$ U enrich., 238U $0.4 \% ; 35 \mathrm{U}(3 \mathrm{~kg})$; Zone: enriched uraniumZone: enriched uranium$6 \%: 235 \mathrm{U}(462 \mathrm{~kg}) \cdot 238 \mathrm{U}$
$67 \%$. $(233 \mathrm{~kg})$; RSC: (Pu-U)C; (142 enrich, $34 \%$; 238 $(142 \mathrm{~kg}) ;{ }^{239} \mathrm{Pu}(73 \mathrm{~kg})$
RZC: a) Test Zone: 7 elements/subassembly; rod length: $91.4 \mathrm{~cm}$; fuel OD: $1.331 \mathrm{~cm}$; tube OD: $1.509 \mathrm{~cm}$; tube wall thickness: subas cm, b) Buffer Zone: $37 \mathrm{~cm}$; fuel $\mathrm{OD}$ : subassembly, rod length: $91.4 \mathrm{~cm}$, fuel $\mathrm{OD}$ thickness: $0.030 \mathrm{~cm}$; c) Driver Zone: 61 elements/subassembly; rod length: 91. $4 \mathrm{~cm}$; ful $\mathrm{OD}: 0.450 \mathrm{~cm}$; tube $\mathrm{OD}$ $01.4 \mathrm{~cm}$; tube wall thickness: $0.030 \mathrm{~cm}$ Total Number of Subas in core: Test-37; Buffer-82; and Driver-

RSC: 61 elements/subassembly, 37 total in core; fuel pin length: $37.6 \mathrm{~cm}$; fuel OD: in core, fuel pin length: $37.6 \mathrm{~cm}$; fube wall thickness: $0.038 \mathrm{~cm}$.
Remote-controlled operations. All core subassemblies will enter or leave containment structure through fuel transfer area. New fuel subassemblies in separate disposal containers will be lowered through acc through access hatch into container-carriage leading to fus transfer port in floor of cell. leamolal of subassembly from container, and subsequent transfers within cell, will be ffected by a fuel-handling machine or manipulator. 

TABLE V. FUEL AND FUEL HANDLING (contd) EBR-I $(7) \quad \begin{aligned} & \text { wt } \mathrm{Pu}, 98.59 \% ; \mathrm{Al}, 1.25 \% \\ & \text { and impurities, } 0.16 \%\end{aligned}$
60 rods per subassembly with 7 subassem-

blies in core; Zircaloy-2 jacket OD,

0.299 in.; jacket ID, 0.257 in.; 3 equi-

spaced Zircaloy- 3 ribs (each 0.049 in. in height) run longitudinally along active portion of rod; fuel slug diam, 0.232 in.

(37.9 kg Pu-max. load); subassemblies are hexagonal; of $2.875 \mathrm{in}$. width and $10815 / 16$ in. length. Fuel portion of rods consists of 4 $\mathrm{Pu}-\mathrm{Al}$ alloy slugs, each 2.121 in. long, giving total core height of $8.484 \mathrm{in}$.
Fuel and blanket rods are transferred directly from opened reactor to a 10 -ton $\mathrm{Pb}$ coffin which is held in place over reactor top with
building crane. A fuel rod is pulled upward building crane. A fuel rod is pulled upward into the coffin through a trapdoor arrangement at bottom. Trapdoor is shut and coffin moved
to wash-pit area. Access to top of opened to wash-pit area. Access to top of opened
reactor is made possible by effective shielding of the coolant, rod extensions, and upper support structure. Inleakage of air is prevented by continuous flow of argon from upper tank region.
47 hexagonal subassemblies in core; 91 fuel elements/subassembly. Fuel elements (Pin-Type, Na-bonded); pin diam: 0.144 in.; pin length: 14.22 in.; fuel tube (SS) OD: $0.174 \mathrm{in.;}$ fuel tube wall thickness: $0.009 \mathrm{in}$. Total core loading is $363 \mathrm{~kg}$ of fuel alloy.

"Fuel handling" includes: removing subassembly from reactor, transferring it to the storage rack, and after a 15-day cooling period, removing it to the disassembly cell. System consists of reactor gripper, mechanism, holddown mechanism, transfer arm, storage rack and disassembly cell gripper mechanism. Reactor gripper mechanism and holddown mechanism are located in the small rotating plug which is in turn eccentrically located in the large rotating plug. Rotation of the two plugs is employed to position the gripper over the desired location in the reactor, and to position the gripper at "transfer position." The reactor cover is also supported by the small plug, rotates with it, with the gripper mechanism and holddown mechanism operating through the cover. (Excellent detailed description given of entire operation in Ref. 9). ZPR-III(10,11) 1) Pu-plates alloyed with Al;
$4.5 \% 240 \mathrm{Pu}$; $0.5 \% 241 \mathrm{Pu}$; 2) $235 \mathrm{U}$, depleted uranium
1) $\mathrm{Pu}-\mathrm{Al}$ : core sizes: $0.085 \times 1.765$ in.; lengths: $0.925,1.925,2.925$ in. Core plates are inclosed in a jacket of 0.012 in. Type 304-L SS; closed by end plugs of same mate rial welded in place. Maximum of $\approx 230 \mathrm{~kg}$ Pu in core. 2) $235 \mathrm{U}$, depleted U: drawer placed in array of square tubes, 2 in. 5 q. Drawers in core are 15 in. long loaded with slugs 2 in. $x 1 / 8$ in.; $1 / 2$ in. . 1 in., 2 in., and 3 in. long ( $235 \mathrm{U}_{\mathrm{U}}$ and depleted U); 17 in. drawers in end blanket section loaded with slugs 1 in. $x 1$ in.; 2 in. 3 in., and 5 . in long (depleted U). A combination of above drawer sizes and slugs are used in intermediate sizes and slugs are used in intermediate
blanket section (depleted U only). (SS and Al blanket section (depleted U
siugs are also in drawers).
Drawers loaded in separate work room, brought into assembly room on a special cart (carrying $\leq 2$ drawers) and placed in position in reactor. Crane service in assembly room itself is furnished by a 5 -ton capacity bridge crane havin a vertical lift of $24 \mathrm{ft}$; contralled by pendant ton capacity monorail hoist with motor driven trolley operates between loading platform through freight operates between loading platform through room; has $13 \mathrm{ft}$ lift and variable and into assembly variable speed control.

*Entire procedure done by men in contact with or near drawers, from vault to loading or 


Bldg). New fuel storage vault is comprised of a room containing 209 sleeves embedded in floor in a $19-$ row by 11 -row array in a $14 \mathrm{in.} \mathrm{sq.} \mathrm{pattern.} \mathrm{Top} \mathrm{of} \mathrm{each} \mathrm{sleeve} \mathrm{is} \mathrm{covered} \mathrm{and} \mathrm{fits} \mathrm{flush} \mathrm{with} \mathrm{floor.}$ Storage tubes, into which new subassemblies are placed, are fitted into floor sleeves. Access area or upper compartment is approx. $17 \mathrm{ft}$ wide by $25 \mathrm{ft}$ long by $18 \mathrm{ft}$ high. Walls are $10 \mathrm{in}$. thick reinforced concrete. Lower compartment is approx. $16 \mathrm{ft}$ wide by $24 \mathrm{ft}$ long by $13 \mathrm{ft}$ high. Walls of variable thickness of reinforced concrete. Decay pool contains permanent storage rack consisting of single tier with spaces for 344 spent subassemblies on a spacing of 14 in. 513 additional (temporary) storage spaces can be made available for entire core unloading. (1. c)

Hallam

Storage cells consist of $40.5 \mathrm{ft}$ long thimbles, provided with plugs and cover plates, suspended into 3 vaults below reactor room floor. Vault I: 111 thimbles (dry); Vault II: 187 thimbles (filled with water as required; Vault III: 85 thimbles (filled with water for cooling--new and spent fuel only).(2.a)

SEFOR

1) Spent: Na-filled rectangular tank in refueling cell. Stores 1-1/2 core loads and 6 instrumented fuel assemblies in Na coolant. 2) New: New fuel hanging racks in storage vault (in-cell). See PSSR, Part II, pp. $5-46$.

FARET

New fuel subassemblies will be stored in thimbles embedded in concrete floor of rear cell area. Irradiated fuel will be stored in wet fuel storage tank located near pressure vessel. Tank will be of double-walled construction and filled with $\mathrm{Na}$. (Heat removal provided for tank). Both storage facilities to be designed to prevent accidental loading to criticality.

EBR-I

Prior to storage or inspection, rods are lowered from coffin through access holes in ceiling of wash room, where they are rinsed in successive baths of alcohol, water and acetone. The fuel rods are stored in a rod form which consists of pipe thimbles embedded in a concrete shield, the top of which is at an elevation corresponding to main floor of bldg. No special provisions have been made for cooling ( 1 MW-full power). Natural circulation and radiation to shielding are sufficient to remove decay heat.

Storage rack is a tank-shaped structure providing 70 storage locations in 3 concentric rows. The rack is suspended by a shaft extending through the disassembly cell, with its drive mechanism mounted on the ceiling of the cell. The rack can be rotated as well as raised to different levels in the primary tank. An empty storage location is positioned below the subassembly, which is suspended from the transfer arm, by rotation of the storage rack. By elevating the storage rack, the subassembly is inserted into a storage location and at the end of upward movement, it is lifted from holding device upon release of transfer arm locking bar. To assure proper vertical movement of rack, a transfer-indicating device is used: a sensing rod extending vertically from disassembly cell ceiling directly to the transfer position. 



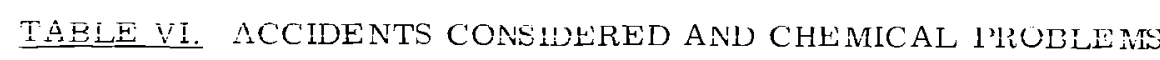

\begin{tabular}{|c|c|c|c|c|c|}
\hline \multirow[b]{2}{*}{ Name } & \multirow[b]{2}{*}{ Maximum Credible Accident (Design Basis) } & \multirow[b]{2}{*}{ Accidents Analyzed } & \multicolumn{2}{|c|}{ Operating Experience } & \multirow[b]{2}{*}{ Chemical Reactions Considered } \\
\hline & & & Accidents & Equipment Failures & \\
\hline FERMI $(1,8)$ & $\begin{array}{l}\text { Melting of some or all of the fuel in one } \\
\text { core subassembly, due to either complete } \\
\text { or partial plugging of the nozzle of that } \\
\text { subassembly, or to a flow restriction } \\
\text { within the subassembly due to radiation } \\
\text { damage which resulted because the sub- } \\
\text { assembly in question was left in the } \\
\text { reactor too long as the result of an } \\
\text { administrative err.or. (No in-plant } \\
\text { or public hazard). }\end{array}$ & 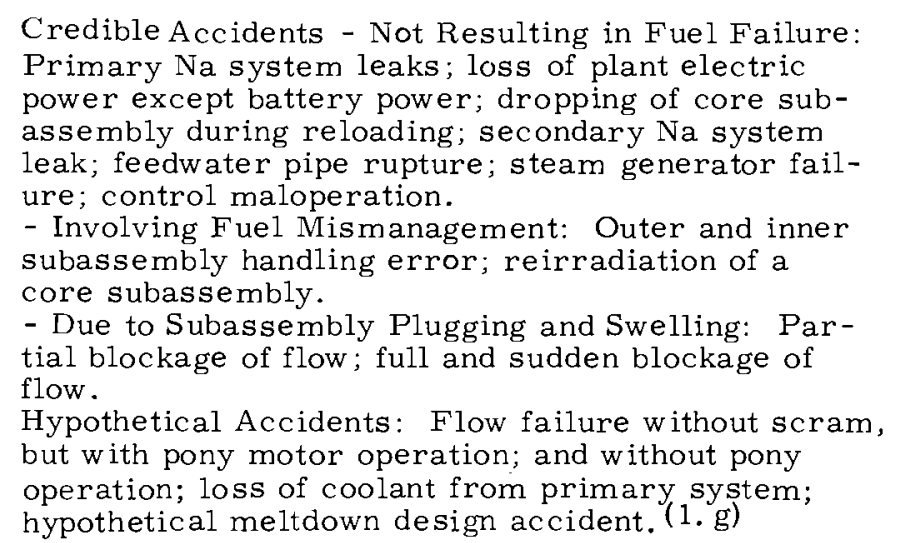 & $\begin{array}{l}5 \text { Oct } 66: \text { An un- } \\
\text { determined number } \\
\text { of fuel elements } \\
\text { melted upon start- } \\
\text { up to full power. }\end{array}$ & & $\begin{array}{l}\text { Tests conducted: } \mathrm{Na}-\mathrm{H}_{2} \mathrm{O} \text { reaction in } \mathrm{Na} \\
\text { shell side of steam generator to determine } \\
\text { size of pressure relief diaphragm needed; } \\
\text { Na and air burning reaction to determine } \\
\text { design temperature and pressure for reactor } \\
\text { building. (1.e) }\end{array}$ \\
\hline Hallam $^{(2-4)}$ & $\begin{array}{l}\text { Dropping of one slug (or its equivalent in } \\
\text { smaller pieces) from fuel handling machine. } \\
\text { Calculated dose rates ( } 1 \mathrm{hr} \text { ) at site } \\
\text { boundary are: Direct radiation, } 6.8 \mathrm{mr} \text {; } \\
\text { Iodine, } 8 \times 10^{-2} \text { mrad; and noble gases, } \\
4 \times 10^{-5} \mathrm{mr} .(2 . \mathrm{c}, \mathrm{d})\end{array}$ & $\begin{array}{l}\text { Meltdown of one element; core meltdown; fuel rup- } \\
\text { ture in wash cell; fuel handling incidents (includes } \\
\text { MCA); pressurization of inert atmosphere; Na spill } \\
\text { (small; large spill following core meltdown); radio- } \\
\text { active Na fire (small, large); steam generator leak; } \\
\text { control rod thimble leak; gas leakage through loading } \\
\text { face shield (1\% failed fuel rods, core meltdown); } \\
\text { gas leakage from primary pump; loss of reactor } \\
\text { heat sink. (2.c,d) }\end{array}$ & $\begin{array}{l}\text { During shutdown- } \\
\text { Na fire in auxiliary } \\
\text { bay of reactor } \\
\text { building }(12-62) ; \\
\text { carbon trap cell fire. }\end{array}$ & $\begin{array}{l}\text { (9-64); Na in- } \\
\text { leakage to } 7 \text { SS - } \\
\text { clad graphite mod- } \\
\text { erator cans. } 4 \text { ( } 4)\end{array}$ & $\begin{array}{l}\text { Oxygen and hydrogen present in Na as impuri- } \\
\text { ties would be absorbed by the Zircaloy-2; } \\
\text { energy released is insignificant. Carbon } \\
\text { present in Na will cause only slight carburiza- } \\
\text { tion of stainless steel at } 950 \text {. F. Moderator } \\
\text { can failure--Na invades porous graphite } \\
\text { causing intracrystalline physical expansion } \\
\text { of about } 2 \% \text {. No significant amounts of } \\
\text { energy released. Na fire in IHX cell. }(2 . c)\end{array}$ \\
\hline SEFOR ${ }^{(5)}$ & $\begin{array}{l}\text { (Maximum Hypothetical Accidents): } \\
\text { 1) Rapid melting of core resulting from } \\
\text { insertion of reactivity by Fast Reactivity } \\
\text { Excursion Device, and loss of coolant } \\
\text { flow; followed by compaction of core into } \\
\text { supercritical mass; 2) Rapid insertion } \\
\text { of reactivity in excess of a dollar by } \\
\text { FRED when core is already well above } \\
\text { design maximum temperature. }\end{array}$ & $\begin{array}{l}\text { 1) Excessive reactivity addition with reflector seg- } \\
\text { ments (rods) } \\
\text { 2) Reactivity addition with coolant system (cold Na } \\
\text { "accident") } \\
\text { 3) Reactivity additions during refueling } \\
\text { 4) Moderator addition to core } \\
\text { 5) Fuel rod bowing } \\
\text { 6) FRED malfunctions } \\
\text { 7) Reactivity insertions with oscillator rod } \\
\text { 8) Loss of coolant pumping power } \\
\text { 9) Loss of pumping power coincident with planned } \\
\text { prompt excursion } \\
\text { 10) Local loss of coolant flow } \\
\text { 11) Mechanical failures in Na coolant system } \\
\text { 12) Reactor vessel failure } \\
\text { 13) Loss of N2 cooling system } \\
\text { 14) Loss of argon cooling system } \\
\text { 15) Ventilation system maltunction (none) } \\
\text { 16) Loss of instrument and breathing air systems }\end{array}$ & & & 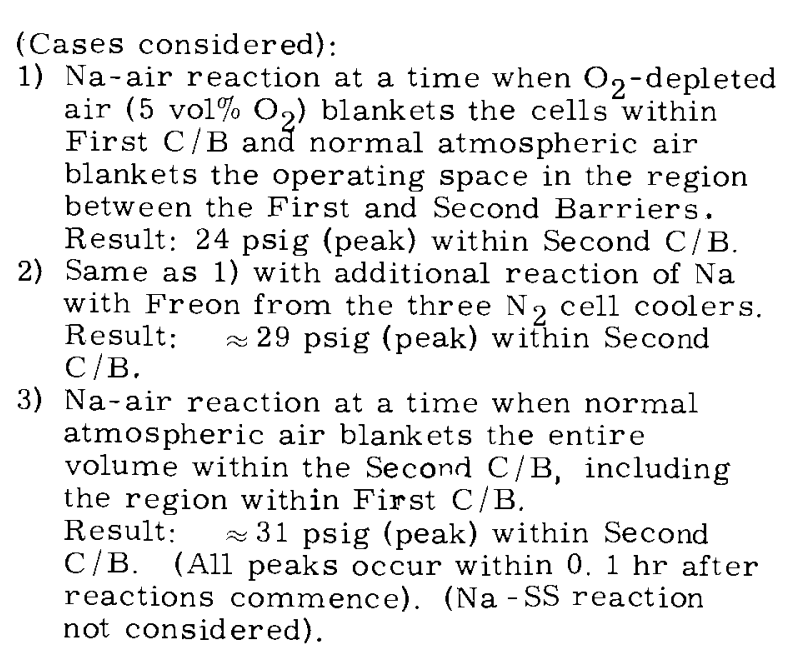 \\
\hline
\end{tabular}



TABLF. VI. ACCIDENTS CONSIDERED AND CHEMICAL PROBLFMS (contत)

\begin{tabular}{|c|c|c|c|c|c|}
\hline FARET $^{(6)}$ & $\begin{array}{l}\text { May be either partial loss of coolant or } \\
\text { coolant flowrate which results in the } \\
\text { gravitational collapse of a molten core, } \\
\text { or the dropping of fuel subassembly. } \\
\text { Either event could, though not neces- } \\
\text { sarily, lead to nuclear accidents involv- } \\
\text { ing a high explosive energy equivalent of } \\
25 \text { to } 30 \mathrm{lb} \text { of TNT. }\end{array}$ & $\begin{array}{l}\text { Fuel Handling and Storage Accidents: } \\
\text { 1) Reactor vessel cover removal } \\
\text { 2) Loss of power during fuel handling operations } \\
\text { 3) Jamming of a spent fuel subassembly } \\
\text { 4) Dropping of a fuel subassembly } \\
\text { 5) Criticality of wet fuel storage tank } \\
\text { Failure of Primary and Secondary Coolant Systems; } \\
\text { Core Meltdown Studies; Release of Fission Products } \\
\text { to Atmosphere }\end{array}$ & & & 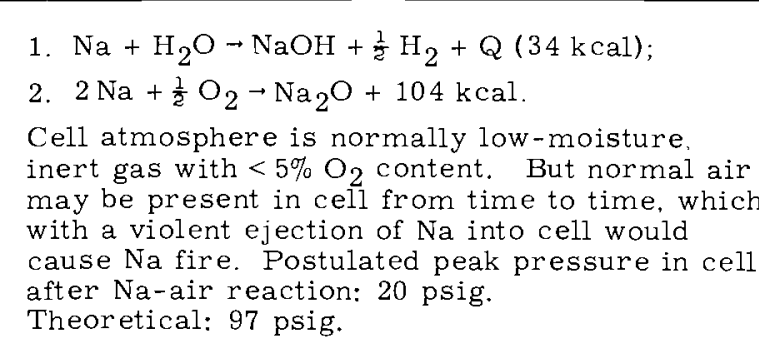 \\
\hline EBR-I ${ }^{(7)}$ & 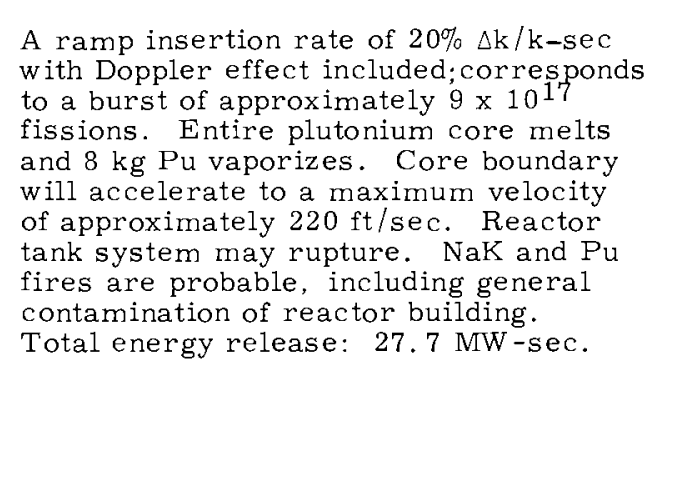 & $\begin{array}{l}\text { 1) NaK leakage and fire } \\
\text { 2) Steam-generator failure } \\
\text { 3) Coolant pump failure } \\
\text { 4) Failure of shutdown cooling system } \\
\text { 5) Reactor tank failure } \\
\text { 6) Failure of cell ventilation } \\
\text { 7) Failure of outer blanket coling } \\
\text { 8) Hydraulic system failure (plattorm elevator } \\
\text { carrying outer blanket and control safety rod } \\
\text { drives) } \\
\text { 9) Outer blanket failure (uranium blanket--not lead } \\
\text { 10) Funket used with Mark IV loading) } \\
\text { 1) Fuel slumping } \\
\text { 12) Loadingent cladding failure } \\
\text { 12) }\end{array}$ & $\begin{array}{l}\text { Nov 55: Partial } \\
\text { meltdown of core } \\
\text { during a transient } \\
\text { experiment carried } \\
\text { out without main } \\
\text { coolant flow; caused } \\
\text { by mechanical design } \\
\text { of Mark I and II } \\
\text { fuel rods and Iore } \\
\text { structural cor cod } \\
\text { bearing points. }\end{array}$ & & 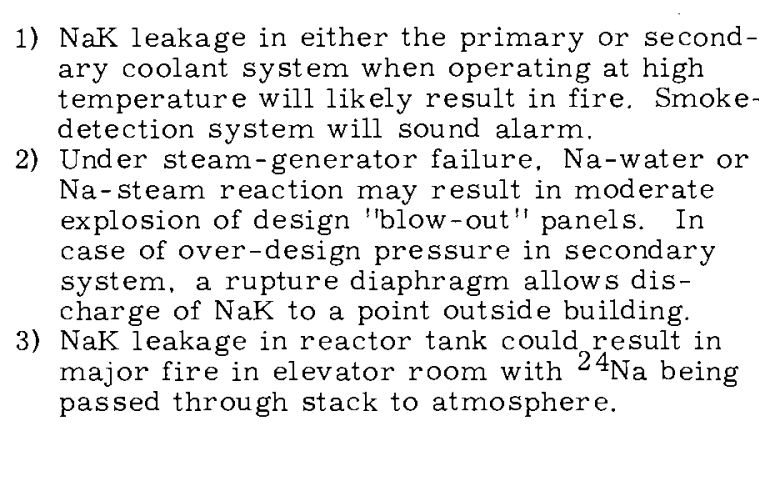 \\
\hline EBR-II ${ }^{(9,3)}$ & $\begin{array}{l}\text { No one accident is termed "the" maximum } \\
\text { accident. However, the design basis acci- } \\
\text { dent is an energy release equivalent to } \\
\text { 300 Ib TNT within the core, a although it is } \\
\text { stated that the primary containment } \\
\text { system could probably contain a release } \\
\text { considerably greater. This energy is } \\
\text { considered to have originated with partial } \\
\text { core meltdown and gravity drop of fuel } \\
\text { into a more reactive configuration. }\end{array}$ & $\begin{array}{l}\text { 1) Six cases are considered where the reactor } \\
\text { is at delayed critical and either at zero or } \\
\text { operating power, when either the control } \\
\text { fuel subassembly is loaded or falls at vari- } \\
\text { ous rates, the two safety rods are driven } \\
\text { in, in an uncontrolled manner, or a single con- } \\
\text { trol rod is driven in, in an uncontrolled manner. } \\
\text { 2) Loss of all pumping power under three dif- } \\
\text { ferent conditions. } \\
\text { 3) Hypothetic containment rupture. } \\
\text { 4) Bowing of fuel elements. }\end{array}$ & . & 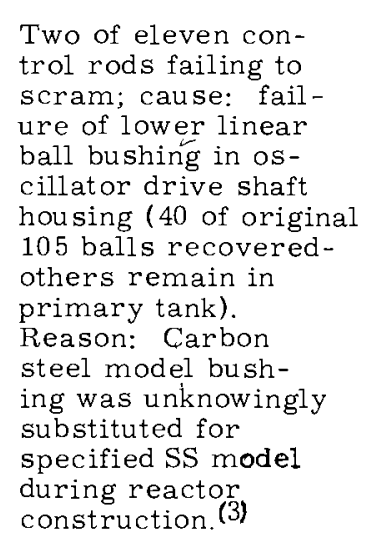 & $\begin{array}{l}\text { Na exposure to atmosphere: } \\
\text { 1) Stagnant pool-results in only small pressure } \\
\text { increase within secondary containment } \\
\text { shell; } \\
\text { 2) Pressurized spray-results in } 38 \text { psig peak } \\
\text { pressure within reactor shell; } \\
\text { 3) Explosive ejection exposure-could result } \\
\text { only from a serious nuclear excursion. } \\
\text { Only under the most severe conditions } \\
\text { would a peak pressure approaching } 75 \text { psig } \\
\text { resulth-highly improbable. } \\
\text { Na exposure to water: Water or other highly } \\
\text { reactive material will not be permitted within } \\
\text { reactor building in sufficient quantity to con- } \\
\text { stitute a potential hazard. }\end{array}$ \\
\hline ZPR-III $(10,11)$ & $\begin{array}{l}\text { Fire in which large part of Pu inventory } \\
\text { was oxidized, damage to sealing of build - } \\
\text { ing occurred, and Pu in quantity of about } \\
200 \mathrm{~g} \text { was released from building. }\end{array}$ & $\begin{array}{l}\text { 1) Action by personnel in assembly room } \\
\text { 2) Action by personnel in control room } \\
\text { 3) Natural catastrophes } \\
\text { 4) Loss of control of fissionable materials } \\
\text { 5) Possible autocatalytic characteristics } \\
\text { 6) Sabotage } \\
\text { 7) Collapse of matrix } \\
\text { 8) Failure of nuclear instrumentation } \\
\text { 9) Startup accident resulting from mechanical } \\
\text { failures. }\end{array}$ & & & \\
\hline
\end{tabular}



TABLE VII. A. SITE

\begin{tabular}{|c|c|c|}
\hline Name & Exclusion Area Radius & $\begin{array}{c}\text { Distance to } \\
\text { Population Centers }\end{array}$ \\
\hline FERMT $^{(1)}$ & $($ minimum): $3280 \mathrm{ft}(1 . \mathrm{f})$ & $\begin{array}{l}\text { Monroe }(23,000) \text {, Mich. } \\
8 \mathrm{mi} \mathrm{SW} \text {. } 30 \mathrm{mi} \text { from Detroit } \\
\text { and } 25 \mathrm{mi} \text { from Toledo (down- } \\
\text { town areas) Stony Pt. }(915) \\
1.5 \mathrm{mi} \mathrm{SSW}(1 . \mathrm{f})\end{array}$ \\
\hline
\end{tabular}

Hallam ${ }^{(2)} \quad$ Site boundary: $1 / 4 \mathrm{mi}^{(2 . \mathrm{b})}$
Nearest population center

(264), $11 / 2 \mathrm{mi} \mathrm{S}$ from site

Nearest small town (3546), 10 $\mathrm{mi}$ to NW. Largest cities in

area are $19 \mathrm{mi} \mathrm{N}(129,000)$ and

$19 \mathrm{mi} \mathrm{S}(12,000) .(2 . \mathrm{b})$
Doses at Exclusion Area Radius and Low Population Zone Boundary Accident Conditions

(Max. Hypothetical Accident-Core Meltdown): (1 yr doses); EAR:I dose to thyroid:163 rem; $v$ dose from

MHA plume:2. 0 rem; direct $\vee$ dose

from Reactor Bldg. : 5.6 rem; Sr-90

dose to bones: 5.7 rem; LPZB: $6 \mathrm{mi}-$ no dose rates given. (1.g)

(MCA-dropping fuel element); under most unfavorable weather conditions (@ site boundary):4. $1 \times 10^{-5} \mathrm{mr}$ (noble gases), $7.8 \times 10^{-5} \mathrm{rads}$ (Iodine); direct radiation to site boundary: $6.8 \mathrm{mr}$. (All doses during first hour). (33\% core meltdown): TID @ site boundary: $820 \mathrm{mr}(1 \%$ per $24 \mathrm{hr}$ ). (Primary Na fire): TID @ site boundary: Cloud Dose:

$63 \mathrm{mr}$; Ground Deposition: negligible; Direct Radiation: 16 R; Max. Ground Deposition $(1.75 \mathrm{mi}): 2.2 \mathrm{R}$. Various TID's at site boundary and in reactor building have been calculated for radioactive cover gas release. $(2 . c)$

SEFOR $^{(5)} \quad 0.4 \mathrm{mi}$

1) Nearest village: (pop. $<30)$ $2 \mathrm{mi}$ due west. 2) Nearest cities: Fayetteville, (pop. 20, 000), $16 \mathrm{mi} \mathrm{NNE;} \mathrm{Fort}$ Smith (pop. 53, 000), $29 \mathrm{mi}$ SSW.
EAR:0. 042 rem (total); LPZB: $0.00096 \mathrm{rem}$ (total); whole body doses. 

TABLE VII. A. SITE (contd)

NAME

FARET $(6)$
Exclusion Area Radixs

$4000 \mathrm{ft}$; distance from EBR-II
Distance to Population Areas

$30 \mathrm{mi}$ due west of Idaho Falls, Idaho

$$
\begin{aligned}
& \text { Doses at Exclusion Ares Rolly } \\
& \text { - Accilon lantiris }
\end{aligned}
$$

1) TID (inhalation) from stack releaseinversion conditions and total cell leakage fraction $\left(\mathrm{L}_{\mathrm{t}}=1.0\right)$ : EAR: $0 \mathrm{rem}$ (thyroid); 0 rem (bone); $0 \mu \mathrm{gm}$ $239 \mathrm{Pu}$; $0 \mu \mathrm{gm} 2{ }^{40} \mathrm{Pu} ; 0 \mu \mathrm{gm}{ }^{2} 41_{\mathrm{Pu}}$; LPZB (14. $4 \mathrm{mi}$ downwind): $72 \mathrm{rem}$ (thyroid); $0003 \mathrm{rem}$ (bone); $3.0 \mathrm{x}$ $10^{-5} \mu \mathrm{gm} 239^{\mathrm{Pu}} ; 5.6 \times 10^{-6} \mu \mathrm{gm}$ $10^{-5} \mu \mathrm{gm}$
$240 \mathrm{Pu} ; 1.9 \times 10^{-6} \mu \mathrm{Pu}{ }^{2} 41 \mathrm{Pu}$.

2) TID (inhalation) at EAR (EBR-II) from stack release-neutral lapse conditions $\left(L_{t}=1.0\right): 28.8$ rem (thyroid); $0.0012 \mathrm{rem}$ (bone); $1.2 \times 10^{-5} \mathrm{\mu gm}$ $239 \mathrm{Pu} ; 2.2 \times 10^{-6} \mu \mathrm{gm}{ }^{240} \mathrm{Pu} ; 7.6 \mathrm{x}$ $10^{-7} \mu \mathrm{gm} 241 \mathrm{Pu}$.

3) Whole-body gamma dose from fission product cloud $\left(\mathrm{L}_{\mathrm{t}}=1.0\right):$ EAR:9.4 rad (neutral lapse cond's); LPZB (14.4 mi downwind):23.6 rad (inversion cond's). 4) TID (inhalation) at EAR from ground level activity release $\left(L_{t}=0.04\right)$ : Inversion; 538 rem (thyroid); 43 rem (bone); $0.45 \mu \mathrm{gm} 239 \mathrm{Pu} ; 0.082 \mu \mathrm{gm}$
$240 \mathrm{Pu} ; 0.029 \mu \mathrm{gm} 241 \mathrm{Pu}$. Neutral lapse: 1.2 rem (thyroid); 0.1 rem (bone) $1 \mathrm{x}$ $10^{-3} \mu \mathrm{gm} 239 \mathrm{Pu} ; 1.9 \times 10^{-4} \mu \mathrm{gm}{ }^{240} \mathrm{Pu}$; $6.6 \times 10^{-5} \mu \mathrm{gm} 24 \mathrm{i}_{\mathrm{Pu}}$.
EBR $-I^{(7)}$

Same as ZPR-III
Nearest residential areas: Arco (pop. 1600), $17 \mathrm{mi}$ WNW and Atomic City (pop. 230), $12 \mathrm{mi} \mathrm{SE}$
Total inhalation dose in fallout area (under stable-inversion conditions): at Highway

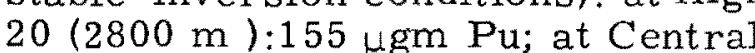

Facilities (5600 m):33 $\mathrm{\mu gm}$ Pu (highest quantities given). Ground contamination at Highway 20 and Central Facilities (stable conditions): at Highway 20:5.6 x $10^{4} \mathrm{\mu gm} \mathrm{Pu} / \mathrm{m}^{2}$; at Central Facilities: $1.2 \times 10^{3} \mathrm{gm} \mathrm{Pu} / \mathrm{m}^{2}$. 



$\frac{\text { Name }}{\text { EBR-II }}{ }^{(9)} \quad \frac{\text { Exclusion Ara. Rortiv: }}{0.6 \mathrm{mi} \text { (site boundary) }}$

TABLE VII. A. SITE (contd) Distance to Population conters

Atomic City, $11 \mathrm{mi}$. With exception of Arco, and a few towns with populations of over 100 , surrounding communities are more than $35 \mathrm{mi}$ distant. All otheran 35 mi distant. All other sites at NRTS are more than $12 \mathrm{mi}$ distant (with exception of TREAT).
ZPR-III $(10,11)$

$2360 \mathrm{ft}$ (adjacent to EBR-I @ NRTS)
Control Facilities, $31 / 2$ mi due E; Atomic City, 12 $\mathrm{mi} \mathrm{SE}$; Arco, $18 \mathrm{mi} \mathrm{NW}$
Doses at Excision Area Radius and Low pepulation Zons Goundary Hypothetical container-rupturing disaster of $10^{20}$ fissions assumed after reactor had been operating at $60 \mathrm{MW}$ for 135 days with no fuel element removal. It was arbitrarily assumed the core contained $125 \mathrm{~kg}$ of 230 . EAR: (airborne fission product activity); fumigation conditions, ave. windspeed: $397 \mathrm{rep}(\beta-$ dose); $6.20 \times 10^{3} \mathrm{R}$ ( $\gamma$-dose); (External hazard from activity deposited on ground; external $\beta+\gamma$ dose during first $3 \mathrm{hr}$ after disaster):1.0 $010^{6}$ rep under high windspeed and total instantaneous washout; (amount of radioisotope which could be accumulated in critical organ by inhalation under daytime conditions -those resulting in overdose): $3.44 \times 10^{2} 4 \mathrm{Ci}\left({ }^{(31} \mathrm{I}\right)$ to thyroid;0. $774 \mathrm{H} \mathrm{Ci}\left(106 \mathrm{Ru}+{ }^{106} \mathrm{Rh}\right)$ to $\mathrm{kid}-$ neys; $540 \mu \mathrm{Ci}\left({ }^{89} \mathrm{Sr}\right)$ to bone; $9.05 \mu \mathrm{Ci}\left({ }^{90} \mathrm{Sr}\right.$ $\left.{ }^{90} \mathrm{Y}\right)$ to bone; $421 \mu \mathrm{Ci}^{91} \mathrm{Y}$ to bone; $217 \mu \mathrm{Ci}$ $(95 \mathrm{Zr}+95 \mathrm{Nb})$ to bone; $574 \mu \mathrm{Ci} 95_{\mathrm{Nb}}$ to bone; $839 \mu \mathrm{Ci}(140 \mathrm{Ba}+140 \mathrm{La})$ to bone; $48.7 \mathrm{\mu Ci}$ $140 \mathrm{La}$ to bone; $96.3 \mu \mathrm{Ci}\left({ }^{144} \mathrm{Ce}+{ }^{144} \mathrm{Pr}\right)$ to (soluble) to bone; $1.32 \mu \mathrm{Ci} 239 \mathrm{Pu}$ (insoluble) to lungs. LPZB (assumed to be about $11 \mathrm{mi}$ ): (airborne fission product activity); fumigation conditions, ave. windspeed:25 rep ( $\beta$-dose). $386 R$ ( $\gamma$-dose); (External hazard from activity deposited on ground; external $B+y$ dose during first $3 \mathrm{hr}$ after disaster): $4.5 \times 10^{3} \mathrm{rep}$ under high windspeed and total instantaneous washout; (amount of radioisotope which could be accumulated in critical organ by inhalation under daytime conditions-overdoses): $2.74 \mu \mathrm{Ci}$
bone; $3.36 \mu \mathrm{Ci}$ to thyroid; $4.30 \mu \mathrm{Y}$ to bone; $6.69 \mu \mathrm{Ci}\left({ }^{140} \mathrm{Ba}\right.$ $+140_{\mathrm{La}}$ ) to bone.

Long exposure: @ $5500 \mathrm{ft}$ for turbulent conditions; <300R@10 mi for stable conditions. 

'IABLE VII. В. LXHAUST VENTHLATION GYGTLM

$\underline{\text { Name }}$

2: above reactor operating

floor and below same. Supply

and exhaust fans in Ventilation

$\mathrm{Bldg}$. provide 150 to $200 \mathrm{cfm}$ of

fresh air to above floor region

of Reactor Bldg. Lower region:

$95 \% \mathrm{~N}_{2}, 5 \% \mathrm{O}_{2}$. (30,000 cfm flow). (1.c)

(a)RMI

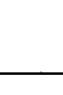

Hallam

3: I. Reactor Area; II. Service

Area; III. Control and Steam
Filtering and Monitoring Arrangements

Absolute filter used in $\mathrm{N}_{2}$ supply system. (1.c)

Monitors: On 6 in. exhaust pipe from

Reactor Building, watertight $\gamma$ scintilla-

ion detector (10 fo $\left.10-\mathrm{Cm}^{3}\right)$; on

3 in.exhaust pipe from machinery dome,

build scintillation detector; in lower reactor

$\left(10^{-2}\right.$ to $\left.10^{3} \mathrm{mr} / \mathrm{hr}\right) .(1 . \mathrm{d})$
Reactor Area (-1/8 in. $\mathrm{H}_{2} \mathrm{O}$ throughout): 3

filter banks ( 2 in operation). Each bank contains 36 roughing filters, 36 pre-

filters, and 36 final filters. Dry scrubber included for hot exhaust during fire.

Service area inlet air filters similar to

those in Reactor Area. Control and Steam

Generator Area-conventional air conditioning system in Control Area (slightly above atmospheric). Reactor atmosphere monitor: scintillation detector and single-channel differential analyzer;range: (10 to $10^{6} \mathrm{cpm}$ ) Control room atmosphere detector (part of an 8-unit system); has range of 0.01 to
$10 \mathrm{mr} / \mathrm{hr}$. (2.a)
SEFOR 2: Reactor and Operations
Makeup air is introduced ahead of filtercooling coil section of recirculation system thereby filtering and dehumidifying the air. 12 independent monitoring channels.
$200 \mathrm{ft}$ high, made of

$1 / 4$ in. plate steel;

ID of $6 \mathrm{ft}$ for lower

der of height. (1. c)
$100 \mathrm{ft}$ above grade with $5 \mathrm{ft}$ ID; exhausts air at $(2 . \mathrm{e})$ 



\section{TABLE VII. B. EXHAUST VENTILATION SYSTEM (contd)}

\begin{tabular}{|c|c|c|c|}
\hline EBR-I & $\begin{array}{l}4 \text { systems: Reactor air supply, } \\
\text { outer-blanket-cooling, shield- } \\
\text { cooling systems (interconnected); } \\
\text { bldg. ventilation system; } \\
\text { cell-ventilation system associated } \\
\text { with primary cooling system cells; } \\
\text { and cell-ventilation concerned } \\
\text { with elevator room and outer- } \\
\text { blanket-handling cells. }\end{array}$ & $\begin{array}{l}\text { Particulate matter in intake side of } \\
\text { reactor supply system is removed by } \\
\text { means of an electrostatic precipitator. } \\
\text { The cooling air for the reflector and shield } \\
\text { and outer-blanket-cooling system is passed } \\
\text { through high-efficiency filters prior to } \\
\text { release up the exhaust stack. } \\
\text { Exhaust-air-activity monitor consists of an } \\
\text { ionization chamber and linear amp. having } \\
\text { range of } 10^{-12} \text { to } 10^{-10} \mathrm{~A} \text {. Amp. output is } \\
\text { registered on a Brown strip chart recorder } \\
\text { located in the control room. To effect proper } \\
\text { discrimination against general background, } \\
\text { activity of exhaust air is compared on same } \\
\text { chart with activity of air sampled from bldg. }\end{array}$ & $\begin{array}{l}\text { Mounted on roof of } \\
\text { main building (height } \\
\text { not given) }\end{array}$ \\
\hline
\end{tabular}

EBR-II 4 systems: Reactor Plant; Laboratory

Bldg., and Process Plant (2)

ZPR-III At least 2: assembly (reactor) room and vault.
Assembly room: Supply system takes outside air through an emergency, compressedair operated intake damper, a 2 in. thick fiber glass filter, 2 finned steam heating coils in series and a $12,000 \mathrm{cfm}$ blower. Exhaust system takes air from ceiling of assembly room and passes it through a 2 . in. thick fiber glass prefilter and $111 / 2$ in. thick Chemical Warfare Service absolute filter. (Exhaust fan is rated at $13,000 \mathrm{cfm}$ @ 5 in. $\mathrm{H}_{2} \mathrm{O}$. Vault: Air supplied through grill from supplyblower, filter, converter unit in boiler room; exhaust system consists of prefilter of fiber glass, C. W. S absolute filter and $300 \mathrm{cfm}$ fan.
$25 \mathrm{ft}$; mounted on roof of assembly building 

Quantity of Wastes

\begin{tabular}{|c|c|c|c|c|c|}
\hline & & & & & \\
\hline Name & Gas & Liquid & Solid & Disposal Systems & Monitoring System \\
\hline Fermi & $9800 \mathrm{scf} / \mathrm{month}^{(1 . \mathrm{ce})}$ & $\begin{array}{l}\text { Subassembly cleaning: } \\
2600 \text { gal/mo; low-level } \\
\text { decontamination opera- } \\
\text { tions: } 350 \text { gal / mo; laundry } \\
\text { if if installed): } 5000 \text { gal/mo; } \\
\text { laboratory sins: } 1500 \\
\text { gal/mo.(1. c) }\end{array}$ & $\begin{array}{l}\text { Abs. filters: } 16 \mathrm{ft}^{3} / \mathrm{mo} \text {; pre-filters: } \\
2.7 \mathrm{ft} 3 / \mathrm{mo} \text { misc. wastes: } 25 \mathrm{ft}^{3} / \mathrm{mo} \text {; } \\
1 \text { ion-exchange resin tank: } 3 \mathrm{ft} 3 / \mathrm{mo} \text {. } \\
\text { Total: } 46.7 \mathrm{ft}^{3} / \mathrm{mo}^{2} \text { (1.c) }\end{array}$ & 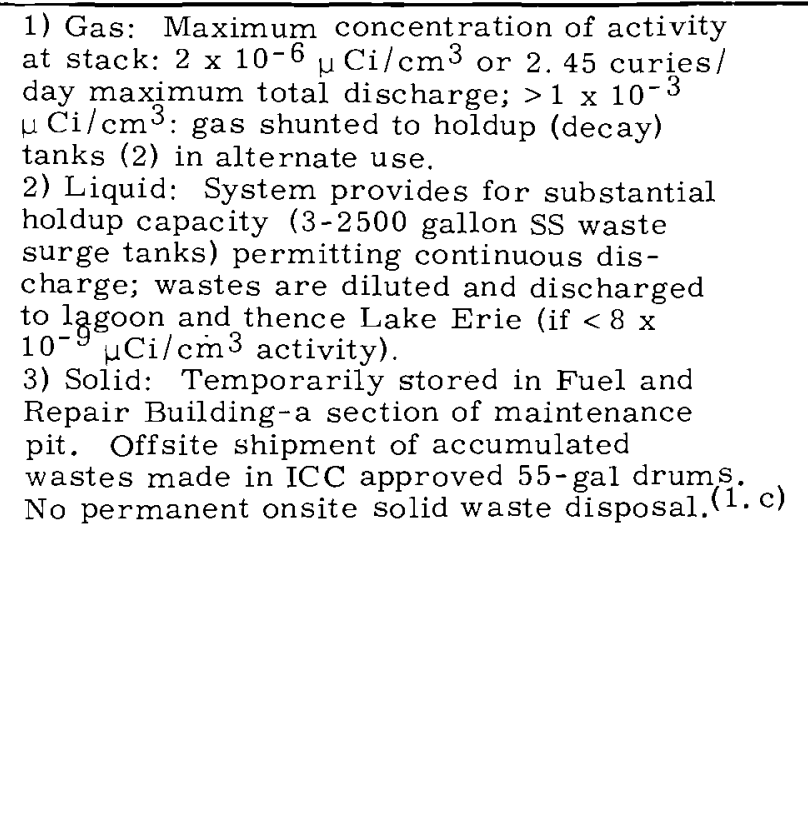 & 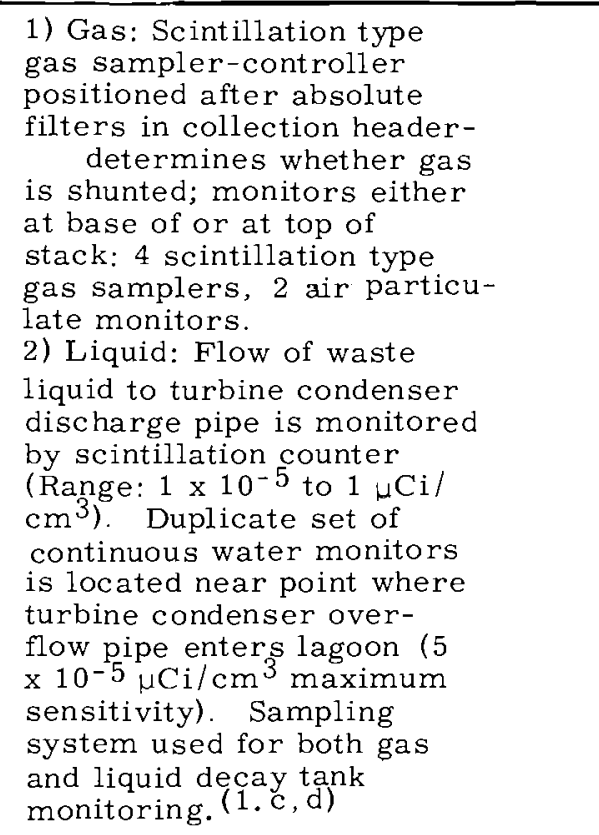 \\
\hline Hallam & 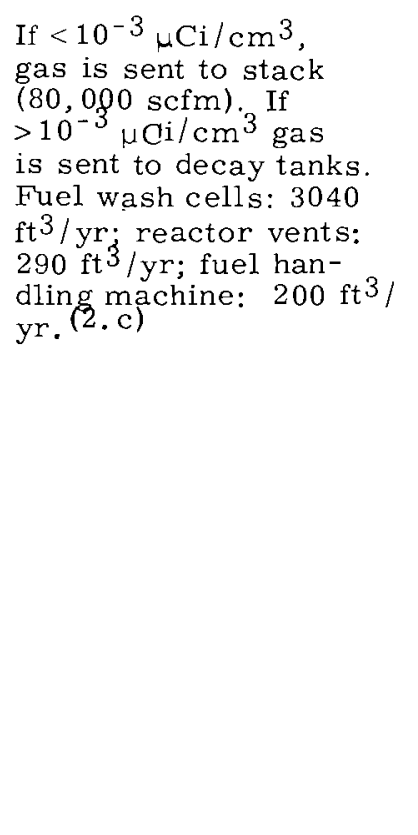 & $\begin{array}{l}\text { Fuel wash cell: } 200 \\
\text { gal/yr; fuel handling } \\
\text { machine wash: } 40 \mathrm{gal} / \mathrm{yr} \text {; } \\
\text { decontamination } \mathrm{room} \text { : } \\
4,469 \text { (total) gal/yr; } \\
\text { maintenance: } 250 \mathrm{gal} / \mathrm{yr} \text {; } \\
\text { laundry: } 16,380 \mathrm{gal} / \mathrm{yr} ; \\
\text { pump wash cel1: } 300 \mathrm{ggil} / \\
\text { yr. (2.c) }\end{array}$ & $\begin{array}{l}\text { Operating experience needed before } \\
\text { making estimate of solid wastes. }(2 . c)\end{array}$ & $\begin{array}{l}\text { 1) Gas: If activity is above } 10^{-3} \mu \mathrm{Ci} / \mathrm{cm}^{3} \text {, } \\
\text { through vent suction tank and compressors } \\
\text { to radioactive gas decav tanks. } \\
\text { 2) Liquid: }<2 \times 10^{-6} \mu \mathrm{Ci} / \mathrm{cm}^{3} \text {, to leaching } \\
\text { field diluted with sanitary sewage or to } \\
\text { ash pit to be diluted with effluent from } \\
\text { coolant tower blowdown. Higher activity } \\
\text { liquids are evaporated and concentrated } \\
\text { with subsequent dilution of distillate into } \\
\text { leaching field or concentrate packaged. }\end{array}$ & 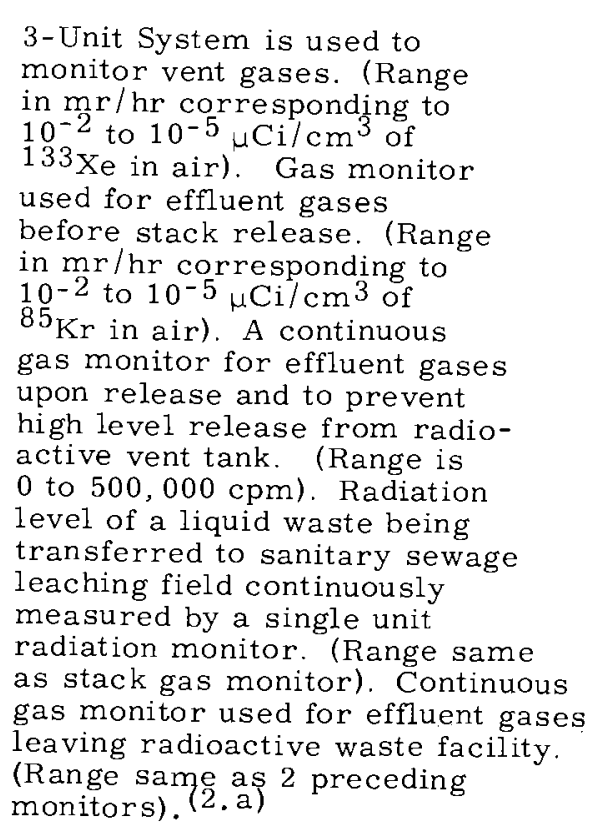 \\
\hline
\end{tabular}



TABLE VII. C. WASTE HFHLUENTS (contd)

\begin{tabular}{|c|c|c|c|c|}
\hline SEFOR & $\begin{array}{l}\text { Reactor cover gas } \\
\text { (75 cf/batch); fuel } \\
\text { storage tank cover } \\
\text { gas }(75 \mathrm{cf} / \mathrm{batch}) ; \\
\text { primary drain tank } \\
\text { vent }(2000 \mathrm{cf} / \mathrm{batch}) ; \\
\text { refueling cell argon } \\
\text { loop vent }(24,000 \mathrm{cf} \\
\text { @ } 100 \mathrm{~cm} / \mathrm{batch}) ; \mathrm{man} \\
\text { lock vent }(400 \mathrm{cf} / \\
\text { batch); and } \mathrm{N}, \text { system } \\
\text { vent }(10 \mathrm{cfm}) \text { (Decay } \\
\text { tank capacity-total: } \\
\text { 20, } 000 \text { scf gas). }\end{array}$ & $\begin{array}{l}\text { System is composed of } \\
\text { the following tanks: } 500 \\
\text { gal, 200 gal; 500 gal } \\
\text { holding; } 500 \text { gal dilute } \\
\text { waste; and } 2000 \text { gal } \\
\text { waste storage. }\end{array}$ & $\begin{array}{l}\text { 1) Gas; facilities provided to } \\
\text { collect, store, filter, dilute and } \\
\text { disperse-long term (60 days) } \\
\text { plant operation without gas } \\
\text { release and no direct routing to } \\
\text { atmosphere. (Once-through } \\
\text { type system). } \\
\text { 2) Liquid: compact flexible } \\
\text { system of storage tanks. } \\
\text { 3) Solid: collection area onsite; } \\
\text { when appropriate, transfer is } \\
\text { made to licensed disposal agency } \\
\text { for offsite disposal. }\end{array}$ & $\begin{array}{l}\text { Routine monitoring of small } \\
\text { waste batches (liquid) before } \\
\text { combining with other wastes. } \\
\text { (RRA) Radiation Alarm pro- } \\
\text { vided at sewer inlet. See Exhaust } \\
\text { Ventilation System; Filtering and } \\
\text { Monitoring Arrangements and } \\
\text { Stack. }\end{array}$ \\
\hline FARET & & & $\begin{array}{l}\text { 1) Gas: Vented to atmosphere via absolute } \\
\text { filters and through stack if levels accept- } \\
\text { able, otherwise it is compressed and stored } \\
\text { pending decay to permissible limits for } \\
\text { release to atmosphere. } \\
\text { 2) Liquid: All lab water from contamination } \\
\text { suspect areas routed to shielded storage } \\
\text { tanks for retention and analyses to determine } \\
\text { ultimate mode of disposal-either onsite } \\
\text { leaching field or pumping to authorized tank } \\
\text { trucks for transport to offsite processing } \\
\text { and disposal areas. } \\
\text { 3) Solid: Nonfueled subassembly scrap } \\
\text { will be canned in the cell and removed in } \\
\text { shielded containers for subsequent disposal } \\
\text { at NRTS burial grounds. }\end{array}$ & $\begin{array}{l}\text { A process gas radiation level } \\
\text { detection system will monitor } \\
\text { the activity levels in waste gas } \\
\text { from the Na system argon blanket } \\
\text { gas and argon atmosphere in } \\
\text { cell, vault, and cavity. Gas } \\
\text { samples monitored by scintillation } \\
\text { type detector. Output fed to } \\
\text { count-rate meter which feeds } \\
\text { alarm circuit. Samples of stack } \\
\text { gas effluent will be taken continuously } \\
\text { and monitored for particulate and } \\
\text { gaseous activity. }\end{array}$ \\
\hline \multicolumn{5}{|l|}{ EBR-I } \\
\hline EBR-II & $\begin{array}{l}\text { Excess make-up argon } \\
\text { gas is vented directly } \\
\text { through filters to the } \\
\text { exhaust stack or to a } \\
\text { retention tank for sub- } \\
\text { sequent disposal. }\end{array}$ & $\begin{array}{l}\text { Recirculating cold trap } \\
\text { system is used for con- } \\
\text { tinuous primary Na purifi- } \\
\text { cation. Cold trap con- } \\
\text { sists of } 500 \text { gal tank } \\
\text { filled with Type 304 SS } \\
\text { wire mesh to provide } \\
\text { supplementary surface } \\
\text { area to enhance Na } \\
\text { crystallization and } \\
\text { deposition. }\end{array}$ & & $\begin{array}{l}\text { Argon vented to the stack is con- } \\
\text { tinuously monitored for activity. } \\
\text { If the activity exceeds the toler- } \\
\text { able level, the gas is pumped into } \\
\text { a retention tank and held until it } \\
\text { decays sufficiently for safe disposal. }\end{array}$ \\
\hline
\end{tabular}





\section{$\underline{\text { REFERENCES }}$}

1. Power Reactor Development Company. Technical Information and Hazards Summary Report, Enrico Fermi Atomic Power Plant, Part B, Revised License Application, AEC Docket No. 50-16, June, 1961.

a. Vol. 1, Section I: Reactor and Plant Design

b. Vol. 2, Section I: Reactor and Plant Design (contd)

c. Vol. 3, Section I: Reactor and Plant Design (contd)

d. Vol. 4, Section II: Plant Operation

e. Vol. 5, Section III: System Verification Programs

f. Vol. 6, Section V: Site and Environment

g. Vol. 7, Section VI: Evaluation of Hazards

2. Final Summary Safeguards Report for the Hallam Nuclear Power Facility, NAA-SR-5700. Atomics International, April 15, 1961.

a. Section 2: Plant Description

b. Section 3: Site

c. Section 4: Potential Hazards and Controlling

Safeguards

d. Section 6: Accident Evaluation and Conclusions

e. Appendix C: Sources of Radioactivity

f. Supplement 4: Question and Answer Section

3. W. J. McCool, et al. Abnormal Reactor Operating Experiences, ORNL-NSIC-17. Oak Ridge National Laboratory, August, 1966.

4. R. M. Mills. Detection and Identification of Failed Moderator Element in HN PF Core from Operating Data, NAA-SR-MEMO10596. Atomics International, October 22, 1964.

5. Preliminary Safeguards Summary Report, Part I, Application to U.S. AEC for Construction Permit and Operating License, SEFOR. Part of AEC Docket No. 50-231. 1965.

6. W. R. Simmons. Preliminary Safety Analysis of the Fast Reactor Test Facility (FARET), ANL-6813, Argonne National Laboratory, August, 1964.

7. R. O. Haroldsen, et al. Safety Analysis Report for the Experimental Breeder Reactor No. 1 (EBR-I), Mark IV Loading, ANL-6411. Arganne National Laboratory, February, , 1963.

8. Nucleonics Week, Vol. 7, No. 41. October 13, 1966.

9. Hazard Summary Report for the Experimental Breeder Reactor No. 2(EBR-II), ANL-5719. Argonne National Laboratory, May, $\overline{1957 .}$

10. R. O. Brittan, et al. Hazard Evaluation Report on the Fast Reactor Zero Power Experiment (ZPR-III), ANL-6408. Argonne National Laboratory, October, 1961.

11. J. K. Long. Safety Analysis of Plutonium Loadings in ZPR-III, ANL-6504. Argonne National Laboratory, September, 1963. 


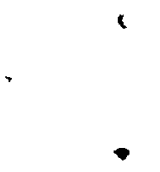

.

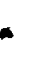

.

•

• 


\section{$\underline{\text { DISTRIBUTION }}$}

No. of

Copies

Atomic Energy Commission, Washington

M. Shaw, Director, RDT

Asst. Director for Nuclear Safety

Analysis \& Evaluation Branch, RDT: NS

Evironmental \& Sanitary Engineering Branch, RDT:NS

Research \& Development Branch, RDT:NS

Assistant Director for Plant Engineering; RDT

Applications \& Facilities Branch, RDT: PE

Components Branch, RDT:PE

Instrumentation \& Control Branch, RDT:PE

Systems Engineering Branch, RDT:PE

Assistant Director for Program Analysis, RDT

Assistant Director for Project Management, RDT

Liquid Metals Projects Branch, RDT:PM

FFTF Project Manager, RDT:PM (3)

Assistant Director for Reactor Engineering

Control Mechanisms Branch, RDT:RE

Core Design Branch, RDT:RE

Fuel Fabrication Branch, RDT:RE

Fuel Handling Branch, RDT: RE

Reactor Vessels Branch, RDT:RE

Assistant Director for Reactor Technology

Chemistry \& Chemical Separations Branch, RDT:RT (2)

Fuels \& Materials Branch, RDT:RT

Reactor Physics Branch, RDT:RT

Special Technology Branch, RDT:RT

2 AEC Chicago Patent Group

G. H. Lee, Chief

R. K. Sharp

268 AEC Division of Technical Information Extension

47 AEC Division of Technical Information Extension

UK/U.S. Fast Reactor Exchange (12)

EURATOM/U.S. Fast Reactor Exchange (35)

$1 \quad$ AEC Idaho Operations Office

Nuclear Technology Division

C. W, Bills, Director 
No. of

Copies

4

AEC Richland Operations Office

C. L. Robinson

Engineering \& Construction Division, J. H. Krema FFTF Project Office (2)

Technical Information Library

1 AEC San Francisco Operations Office

Director, Reactor Division

$4 \quad$ AEC Site Representatives - PNL

P. G. Holsted i2;

L. R. Lucas

A. D. Toth

$4 \quad$ AEC Site Representatives

Argonne National Laboratory

A romics International

Atomic Power Development Associates

Gerieral Electric Company

2 Argonne National Laboratory

R.A. Jaross

LMFBR Program Office

2 Atomics International

L. E. Glasgow

R. W. Dickinson

1 Atomic Power Development Associates

B. V.D. Farris

2 Babcock \& Wilcox Company

S. H. Esleeck

T. P. Farrell

1 Combustion Engineering

W. P. Staker

$2 \quad$ General Dynamics Corporation

D. Coburn 
No. of

Copies

4

General Electric Company

Karl Cohen (3)

Bertram Wolfe

1 Idaho Nuclear Corporation

D. R. deBoisblanc

$1 \quad$ PNL Representative

N. A. Hill (ZPR III)

1 Stanford University

R. Sher

5 Westinghouse Electric Corporation

J. C. R. Kelly

114 Battelle-Northwest

G. E. Akre

W. G. Albert

S. O. Arneson

E. R. Astley

J. M. Batch

R. A. Bennett

J. R. Boldt

C. L. Boyd

D. C. Boyd

C. L. Brown

W. L. Bunch

C. P. Cabell

A. C. Callen

J. R. Carrell

W. E. Cawley (2)

W. L. Chase

T. T. Claudson

P. D. Cohn

D. L. Condotta

J. H. Cox

G. E. Culley

G. M. Dalen

J. M. Davidson

V. A. DeLiso

D. R. Doman

G. E. Driver

R. V. Dulin

J. F. Erben

L. M. Finch

R. C. Free 
Battelle-Northwest (contd)

E. F. Garrett

S. M. Gill

V. W. Gustafson

R. A. Harvey

B. R. Hayward (2)

J. W. Helm

R. J. Hennig

G. M. Hesson

J. E. Irvin

P. L. Hofmann

B. M. Johnson

H. G. Johnson

R. W. Johnson

$J$. H. Kinginger

W. C. Kinsel

D. D. Lanning

H. D Lenkersdorfer

C. W. Lindenmeier

H. E Little

W. W Little

C. E. Love

D. E Mahagin

W. B McDonald

M. H. Meuser

R. A. Moen

C. A. Munro

D. MI, Nero

M. G. Patrick

J. A. Perry

R. E. Peterson

W. E. Roake

J. D. Schaffer

F. H. Shadel

D. W. Shannon (2)

R. E Shaver (10)

D. E. Simpson

C. R F. Smith

R. J. Squires

D. D. Stephenski

G. H. Strong

C. D. Swanson (4)

J, W. Thornton

J. C. Tobin

K. G. Toyoda

M. A, Vogel

D. M. Walley

J. H. Westsik
I. A. Whinery

R. D. Widrig

T. W. Withers

N. G. Witienbrock (10)

M. R. Wood

F. W. Woodfield

EFTF File

Technical Information Files (5)

Technical Publications 